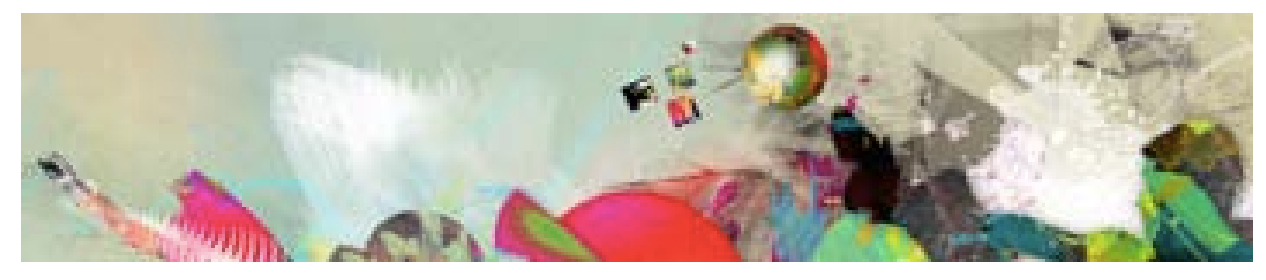

\title{
El estado del arte en la Comunicación Estratégica $^{1}$
}

\section{Strategic Communication: the state of the art}

\author{
Rafael Alberto Pérez ${ }^{(*)}$ \\ Universidad Complutense de Madrid - España \\ estrategia@rafaelalbertoperez.com
}

\begin{abstract}
Resumen
Todo indica que el problema de bosquejar el estado del arte de la comunicación estratégica no es tanto concretar el estado de la cuestión (dónde estamos) cuanto concretar la cuestión cuyo estado se pretende precisar (de qué fenómeno estamos hablando). Partiendo de esta inquietud el autor realiza un recorrido por cuatro campos de conocimiento relacionados: los estudios de Estrategia y de Comunicación, los más específicos sobre "comunicación estratégica” y aquellos estudios sobre estrategia y comunicación realizados desde las ciencias de la vida. Para concluir que hay dos rasgos que caracterizan el momento actual: (1) los fuertes desplazamientos de la comunicación y la estrategia hacia los nuevos paradigmas científicos, y (2) la tendencia a
\end{abstract}

\begin{abstract}
There is every indication that the problem for sketching the state of the art in Strategic Communication is not a question of clarifying where we are in this subject, but of defining which is the phenomenon we are speaking of. Starting from this point, the author makes a review of four fields related to Strategic Communication: Strategy Studies, Communication Studies, specific studies about Strategic Communication and studies about Strategic Communication carried out by Life Sciences. The author concludes that there are two features that characterize the current period: (1) the strong movements of Communication and Strategy towards the new Scientific Paradigms. And (2) the trend, in both
\end{abstract}

1 Ponencia inaugural de la VIII Bienal Iberoamericana de Comunicación, Puebla, México, 7 de septiembre 2011. 
la encarnación de ambos fenómenos en seres humanos (relacionales) y en sujetos colectivos (organizacionales). El autor sugiere dar un nuevo salto y estudiar la comunicación estratégica como un fenómeno biológico y no solo social, político o económico. Todo ello en la idea de que esa encarnación de la comunicación estratégica en la trama de la vida, habrá de facilitar la tan ansiada unificación del campo de estudio.

Palabras clave: unificación del campo de estudio, estrategia, comunicación, encarnación, organización, ciencias de la vida. fields, towards personification in individuals (relations) and in collective individuals (organizations). As a turning point, the author suggests the study of Strategic Communication not only as a social, political or economical phenomenon but as a biological one. The reason for this proposal is that the incarnation of Strategic Communication in the fabric of life will facilitate the unification of this field of study.

Keywords: unifying the field of Strategic Communication, strategy, communication, incarnation, organization, life sciences. 


\section{Planteamiento. En busca del fenómeno perdido (CON PERMiso de MARCEL Proust)}

\subsection{El estado de la cuestión, pero ¿de qué cuestión?}

"No basta con utilizar las mismas palabras, es
necesario utilizar las mismas palabras referidas
al mismo género de acontecimientos interiores".

Nietzsche

Vivimos en un mundo en el que las relaciones que los científicos establecen frente a sus objetos de conocimiento se encuentran expuestas a permanentes cambios. Por ello, la misión de un estado del arte es responder a la pregunta dónde estamos con respecto a un fenómeno dado (que hay que concretar previamente).

Pero no se trata tanto de ir "tras las huellas" sino de saber a qué futuro nos conducen esas huellas. Para ello se ha de dibujar una visión clara y global del panorama actual de la temática considerada, sus logros pero también los retos planteados y las líneas de investigación abiertas. Esa es la tarea que tengo por delante, pero además ha de hacerse desde una lectura crítica, analítica y objetiva de los trabajos más significativos. Digo objetiva, a sabiendas de que esa objetividad nunca se podrá alcanzar, pues toda crítica implica un cierto número de premisas y asunciones que constituyen su sustrato ideológico: "Esta tarea no puede ser neutra: se tiene que hacer desde la perspectiva de alguien, preferentemente de una parte interesada que hable de una actividad en la cual participa" (Varela, 1988).

Pues bien, un deber elemental de transparencia me lleva a recordarles que yo cumplo ese requisito negativo que marca Varela: no soy neutral. Soy parte interesada en esta temática como consultor ( 45 años), como docente (38 años) y como escritor (35 años). Aquellos que me han leído saben que mi interés se centra en el ser humano relacional, que soy de los que piensan que las capacidades estratégicas y comunicativas son parte constitutiva de esa humanidad y, que cuando escribo, uso más la expresión "estrategias de comunicación" que la de "comunicación estratégica". Confío que al final de mi exposición se entiendan mis posiciones que, por otra parte, no deberían nunca sesgar el relato. 
Lo cierto es que, casi sin darnos cuenta, hemos entrado en materia. Un primer recorrido por la literatura sobre comunicación estratégica nos hace sospechar que los investigadores no se han esforzado demasiado por consensuar el fenómeno que debería ser su objeto de estudio. Todo indica que el problema aquí no es tanto concretar el estado de la cuestión (dónde estamos) sino concretar la cuestión cuyo estado se pretende precisar (de qué fenómeno estamos hablando). Y por ello, cuando encontremos textos sobre "comunicación estratégica" y "estrategias de comunicación", tendremos que preguntarnos a qué se refieren los distintos autores y si las discrepancias que podamos encontrar responden a una cuestión semántica o conceptual.

Las preguntas se agolpan: ¿Estamos ante un interfaz de dos categorías o ante una categoría adjetivada?, cante un tipo de estrategias o ante una subcategoría de la comunicación?, ¿ison todas las estrategias comunicativas?, ¿'son todas las comunicaciones estratégicas?, ¿hay una diferencia real entre ambas expresiones?, ¿en qué sentido califican "comunicativo" y "estratégico"?, ¿versus qué se califica?, ¿qué son las estrategias cuando no son comunicativas y qué son las comunicaciones cuando no son estratégicas? Pero, sobre todo, ¿̇e qué estrategia y de qué comunicación estamos hablando?

Mucho trabajo por delante pero el tema lo amerita. Estamos ante una cuestión relevante: relevante para el investigador que necesita saber qué fenómeno ha de estudiar; relevante para el comunicador que necesita saber que le aporta a sus comunicaciones el calificativo de estratégicas; también para el estratega, que necesita saber qué aporta la comunicación a su estrategia; relevante para el ejecutivo que tiene que entender por qué la comunicación tiene que dejar de ser táctica para integrase en las funciones estratégico/directivas. Y, finalmente, relevante para la unificación del campo de estudio porque solo se puede converger en torno a algo bien definido y consensuado.

\section{Conclusiones 1.1}

Estamos ante un objeto de estudio altamente elusivo y con múltiples abordajes académicos. Ni la estrategia ni la comunicación tienen acuñadas conceptualizaciones claras y consensuadas. A la vista de ello, antes de zambullirnos en la literatura y ponernos a analizarla, tal vez la primera tarea sea comprobar si la "comunicación estratégica" es un artilugio académico o se trata de un fenómeno real. ¿Y si salimos a la calle y echamos un vistazo ahí fuera?

Mediaciones Sociales, № 10, I semestre 2012, pp. 121-196. ISSN electrónico: 1989-0494. DOI: http://dx.doi.org/10.5209/rev_MESO.2012.n10.39684 


\section{2. ¿Está nuestro fenómeno ahí fuera?}

A veces da la impresión de que los académicos complicamos las cosas haciendo oscura, a través de nuestras disquisiciones conceptuales, una realidad tan asequible como evidente. ¿Es este uno de esos casos? Ante la duda deberíamos asomarnos a la ventana y echar un vistazo. Fenómenos escurridizos en su descripción son, en cambio, fáciles de identificar por cualquiera de nosotros. La "vida" es uno de ellos. Todos sabemos distinguir un organismo vivo de otro que no lo es. Pero pruebe el lector a describirla. Dado que "estrategia” y "comunicación” son expresiones de la vida, tal vez de ahí provenga la dificultad para describirlas.

Pues bien, cuando nos asomamos a la ventana de la realidad lo que vemos es una fracción de un mundo al que todos queremos cambiar para que se cumplan nuestras metas. Un mundo que se mueve y se reconfigura constantemente. En parte por inercia, en parte por azar y, en otra parte, por la voluntad de todos y cada uno de los que habitamos el planeta. Unos con más poder de transformación que otros. En este momento, en algún lugar, grupos de emigrantes se afanan por conseguir un puesto de trabajo con el que sobrevivir en sus nuevos entornos, mientras, en otros lugares, hay cirujanos que tratan de "retocar" el corazón dañado de sus pacientes, en un intento desesperado por alargar sus vidas. Y no muy lejos, a esta misma hora, en alguna escuela o universidad hay profesores que intentan motivar a sus alumnos y transmitirles su conocimiento. Tal vez en ése aula haya un letrero que afirme: "La educación es el futuro". Esos intentos de transformación forman parte de nuestra cotidianidad, pero son más visibles y notorios en la esfera pública, donde los grandes operadores utilizan estrategias fríamente pensadas y planificadas en busca de una mayor eficacia en sus intentos de cambiar sus entornos. El Yearbook of International Organizations (1995/1996) editado por la Union of International Associations (UIA) nos habla de 20.000 organizaciones internacionales que implementan anualmente la nada desdeñable cifra de 29.542 estrategias a través de 52. 406 programas. Por su parte el "Informe Bertelsmann" (1999) nos aporta una larga nómina de operadores estratégicos: partidos políticos, tribunales, patronales, sindicatos, instituciones educativas, medios de comunicación, instituciones religiosas, fundaciones, intelectuales, asociaciones a los que hay que añadir varios miles de fabricantes y distribuidores que 
compiten por sus mercados locales e internacionales, mas las compañías que los trasportan y aseguran.

Todas esas intervenciones tienen en común que están orientadas al futuro. En parte es algo inexorable, cada uno de los actos de transformación que hacemos aquí y ahora tendrá efectos después. Pero también es algo calculado, son conductas orientadas a unos resultados futuros. Sabemos que una parte de ese esfuerzo estratégico se canaliza a través de la comunicación. No es una sospecha, hay toda una industria de consultores y agencias dedicada a ello y sus cifras de negocio se publican cada año en las revistas especializadas. Lo que ocurre es que no siempre se llamó comunicación estratégica. La palabra estrategia venía cargada de violencia y limitada al ámbito castrense. Hubo que esperar a 1923 para encontrar la primera referencia documentada en que se vinculase "estrategia" y "comunicación". Fue en el libro "Scientific Advertising" (Hopkins, 1923). Dos viejos compañeros de viaje recibían así su acta de matrimonio y ya nunca más se separarían. No es una frase retórica, "estrategias de comunicación" entrecomillado da 5.770.000 resultados en Google; "comunicación estratégica" 1.730.000; y "comunicación estratégica organizacional" 785.000 (consulta del 09/08/2011).

Pero para transformar el mundo, antes tenemos que saber en qué mundo estamos. Y sabemos de ese mundo cambiante gracias a los telediarios y las noticias de los medios de comunicación. Pero esas noticias no son asépticas. Alguien las produjo, formateó, distribuyó, seleccionó y decidió difundirlas. La realidad no nos llega en estado puro sino intermediado en función de los intereses de los grupos de comunicación y sus patrocinadores. Lo cierto es que si miramos a nuestro alrededor hay pocos espacios que estén libres de influencia. Cada uno de nosotros intentamos influir en nuestra pequeña esfera doméstica, para hacerla más propicia. Y como ejemplo bastaría con preguntarnos: ¿quién renuncia a formar a sus hijos?

La buena noticia es que hoy se prefiere utilizar estrategias de comunicación que hacer uso de la fuerza. La sociedad nunca ha sido tan dialogante. Pero este hecho ha merecido diferentes opiniones. Algunos expertos hacen una lectura positiva y consideran que las estrategias de comunicación están llamadas a jugar en el siglo XXI un papel articulador y de pegamento de las fracturas sociales (Alberto Pérez, 2001). Aspiran a que la comunicación sea el motor del cambio social y a que este cambio surja conversacionalmente

Mediaciones Sociales, № 10, I semestre 2012, pp. 121-196. ISSN electrónico: 1989-0494. DOI: http://dx.doi.org/10.5209/rev_MESO.2012.n10.39684 
del propio grupo social, de acuerdo a parámetros definidos por ese mismo grupo y no impuestos desde fuera (Massoni, 1990). Es la comunicación participativa para el cambio social de Luis Ramiro Beltrán (2000) y Alfonso Gumucio Dragón (2001, 2009), una idea que saldrá reforzada con las nuevas tecnologías y las redes sociales. Pero no todo son lecturas positivas. Un sector crítico enfatiza los aspectos disfuncionales y denuncia que nunca fuimos tan manipulados. Proponen una educación para la comunicación y nos advierten de los peligros de una intermediación mediática que nos "coloca" otros modelos del mundo. Descubrimos así que ni la información ni el entretenimiento son inocentes y que la semiosfera de Lotman (1998) se ha ido convirtiendo en una enorme semio/strateg/sfera (Alberto Pérez, 2001).

Tampoco todo son buenas noticias. En 1994 la Encyclopedia of World Problems and Human Potential (UIA, 1994) identificó los principales problemas del mundo. Pero en estos 7 años las cosas no han mejorado y el escenario que nos presentan Jerome C. Glenn, Theodore J. Gordon y Elizabeth Florescu en su 2010 State of the Future, (2010) es menos deseable si cabe (Treviño y Arango, 2011).

Vemos así que las comunicaciones estratégicas forman parte del actual escenario pero se mueven bajo un fuego cruzado: mientras los medios de comunicación nos hablan de problemas que necesitan de una gran capacidad estratégica y de diálogo, los expertos nos dicen que 5 de cada 7 estrategias fracasan y las llamadas conversaciones de paz se eternizan mientras las balas (y las piedras) siguen hablando su propio lenguaje. Crece así la sensación de que se desperdicia una parte importante del dinero y del esfuerzo que se dedica a desarrollo y fines sociales. En este contexto, algunos expertos nos preguntamos si parte de la culpa de tantos fracasos y del enquistamiento de tantos problemas no la tendrá la propia Academia. Si no estaremos dándoles a los operadores públicos teorías más propias del XVII que del XXI, y por lo tanto inadecuadas para afrontar los retos de los nuevos contextos. 


\section{Conclusiones 1.2}

Esta incursión en el mundo real nos confirma que el fenómeno de las estrategias de comunicación existe y es cada vez más explícito. Y que muchas de esas estrategias se concretan en su ejecución en un sinnúmero de comunicaciones que, al formar parte de una estrategia, merecen llamarse estratégicas. Encontramos una relación entre la parte y el todo. Pero lo que no hemos podido encontrar es la "comunicación estratégica" en singular, y no la hemos encontrado sencillamente porque no existe, es una categoría y las categorías solo habitan en la mente de las personas. No son fenómenos sociales. Como ya apuntó Wittgesteing: "no existe el habla, lo que existe es el lenguaje de la vida cotidiana que se concreta en actos de habla". La buena noticia es que sí hemos encontrado "actos comunicativos estratégicos".

\subsection{La propuesta metodológica}

Ahora que sabemos que estamos ante un fenómeno real vamos a rastrearlo y concretarlo. Lo aconsejable es armarnos no solo de paciencia sino, sobre todo, de una buena metodología. La que vamos a seguir comprende 7 fases y de una fase cero.

- Fase Cero. Establecer el objetivo y las preguntas de la investigación. Ta cumplida, véase 1.1.

- Fase 1. Asumir una determinada perspectiva y tratar de ver la cuestión con ojos nuevos: La mía es sistémica, compleja, pragmática, constructivista y evolucionista.

- Fase 2. Identificar el sistema en que se ubica el fenómeno considerado: Desde esa perspectiva la comunicación estratégica forma parte del sistema de las interacciones de los seres humanos entre sí y con su entorno. Ese es el sistema que vamos a indagar.

- Fase 3. Establecer si estamos ante un fenómeno que permite un abordaje disciplinar o que exige un enfoque transdisciplinar: El fenó- 
meno de la comunicación estratégica es poliédrico. Más de XXV siglos de historia documentada han configurado un fenómeno rico en facetas que reclama un enfoque transdisciplinar.

- Fase 4. Simplificar sin renunciar a la diversidad. Aunque para ello tengamos que caer en algunos reduccionismos que habría que asumir como mal menor: La mejor manera que conozco para simplificar sin perder la complejidad y la riqueza de un fenómeno es tomar distancia - a ser posible por elevación - tratando de alcanzar una visión global panorámica que nos permita apreciar el escenario de escenarios que componen la trama.

- Fase 5. Identificar los distintos subsistemas: De la variedad de subsistemas en que se puede descomponer el sistema de interacciones humanas nos conciernen especialmente tres: los estudios sobre Estrategia; los estudios sobre Comunicación y los estudios más específicos sobre comunicación estratégica. Pero hay un cuarto subsistema que entendemos menos explorado pero no por ello menos relevante: aquella parte de las Ciencias de Vida que estudian el fenómeno desde una perspectiva biológica/ evolutiva.

- Fase 6. Reconocer sobre el terreno esos distintos subsistemas y recorrer las diferentes trayectorias de la comunicación estratégica: Identificar las fuentes; sistematizar y resumir las distintas teorías explicativas del fenómeno marcando los puntos más relevantes de sus trayectorias.

- Fase 7. Abrirnos paso por sus senderos en busca de una explicación que cumpla los objetivos y requisitos que hemos enunciado: Analizar las líneas de investigación en curso con especial atención a las hegemónicas pero también a las más emergentes; situar el escenario actual de los debates y su proyección a futuro.

Las 5 primeras fases son conceptuales y las hemos de cumplimentar antes de comenzar nuestra exploración a fin de que nuestra mirada sepa ver lo que el viaje pueda ofrecernos. 


\section{Conclusiones 1.3}

Nuestro mapa dibuja un escenario de escenarios, una jungla de junglas. La metáfora selvática describe bien mis sensaciones pero, para ser honestos, no es mía: se la robé a Mintzberg y a su "Strategy Safari”. En la medida en que nuestro objeto de estudio, representa el interfaz de dos saberes distintos, se abre ante nosotros un camino circular en el que el estudioso ha de seguir las dos direcciones a sabiendas de que, ambas van a encontrarse. Ahora con este mapa in mente y las maletas ya hechas ya podemos descender al terreno.

\section{EXPLORACIÓN. LA JUNGLA DE LOS SENDEROS QUE SE BIFURCAN Y AL FINAL SE ENCUENTRAN (CON PERMISO DE JORGE LUIS BORGES)}

\subsection{La jungla de la Estrategia}

"Discussion of the role of the communications function in the strategic decision making process has been neglected in the strategy literature, which views communications as a primarily tactical function. This contrasts with the communications literature which posits a more overt role for communication (with particular reference to corporate communications and public relations) in the strategy process".

Danny Moss / Gary Warnaby

La Estrategia es uno de los dos campos de estudio que acotan el fenómeno que queremos estudiar. De la Estrategia nos interesa aquí su relación con la Comunicación. En qué sentido la puede calificar o contener. Y para ello tenemos que poner nuestra atención en sus trayectorias, concepciones y conexiones.

a) El origen del fenómeno: La Estrategia antes que una teoría o una disciplina es una capacidad de todos los seres vivos. Las teorías llegarían después. Una capacidad orientada a la supervivencia de un ser que no 
estaba solo y tenía que convivir con una naturaleza a menudo hostil y con otros seres, fuerzas y sistemas que podían ayudarle o perjudicarle para el logro de sus metas.

b) Dimensiones: Cuando hablamos de Estrategia hemos de diferenciar entre: estrategia: la capacidad; Estrategia (con mayúscula): la disciplina y la categoría académica (ambas coinciden, lo que no ayuda); estrategar: el proceso; y estrategias (en plural y con minúscula): las diferentes rutas de comportamiento, paquetes de decisiones, alternativas, etc. elegidas para alcanzar nuestras metas. A lo largo de la historia todas y cada una de estas dimensiones del término "estrategia" van a sufrir distintas conceptualizaciones que iremos comentando.

c) La palabra: El término estrategia aparece en Grecia. Significa liderar la tropa. Es evidente que en China, Sun Tzu no utilizó la palabra estrategia. En su lugar empleó $(J i)$ que en chino arcaico tiene un sentido muy amplio, pues además de estrategia significa proyecto, plan, idea, estratagema, táctica, artimaña, truco. (Alberto Pérez, 2001). A finales del siglo XVIII, el término "estrategia" comienza a extender sus usos a otros ámbitos distintos del militar. La Real Academia Española lo introdujo en su Diccionario a mediados del siglo XIX. Pero ha sido tras el fin de la II Guerra Mundial, cuando su uso se ha popularizado considerablemente. En la actualidad se aplica en sentidos y contextos muy diferentes. En el lenguaje común suele designar el "cómo" se logra una meta. Y consecuentemente se entiende por "estratégico" aquello que sirve para lograr objetivos. También aquello que es muy relevante. Una tercera acepción nos remite a las decisiones que se adoptan a medio o a largo plazo. Y una cuarta a las decisiones que se toman al nivel directivo más alto.

d) El concepto: Aunque se suele creer que la Estrategia nace como una reflexión sobre el uso beligerante de la fuerza, los primeros textos nos indican que surgió en un contexto de defensa. Así en Grecia el detonante serían las derrotas infligidas por los medos. Y en China, la violencia entre los distintos reinos previa a la unificación. No es casual que una de las obras más antiguas que se conserve se titule "Cómo defenderse y sobrevivir sitiado” (Eneas el Táctico, s. IV a.c.). La fórmula por la que se optaría para resolver ese viejo problema haría historia: aplicar anticipativamente, inteligencia y cálculo a la confrontación 
probable. Pero si esos fueron sus orígenes, a golpe de siglos y de teorías fueron surgiendo otras concepciones. 5 para Mintzberg (1987); 6 para Arnoldo Hax (1990); y 8 para Rafael Alberto Pérez (2001): la estrategia como anticipación, decisión, método, posición/ventaja; marco de referencia; perspectiva/visión; discurso y lógica de acción; y como relación con el entorno.

e) La literatura: Los textos sobre Estrategias remontan al siglo $\mathrm{V}$ a.c. La Estrategia que hoy conocemos es el resultado de cinco genealogías de conocimientos que viven vidas casi separadas para terminar encontrándose en el siglo XX. Interesa destacar que una de esas genealogías es comunicacional: se inicia con la retórica, sigue con la propaganda y llegaría al siglo XX con la acción comunicativa de Jurgen Habermas. Se localiza pues ya en el origen una conexión importante entre Estrategia y Comunicación. Encontramos otra conexión importante, aunque corta en el tiempo, entre la teoría de la acción social de la Comunicación y la Estrategia en Maquiavelo.

f) Las teorías: La estrategia ha tenido hasta ahora tres grandes paradigmas: el militar, el científico/matemático y el económico/managerial. Cada uno ha generado sus propias conceptualizaciones y cada uno ha tenido una relación distinta con la comunicación.

g) El paradigma militar (s.V a.c hasta nuestros días): Concibe la Estrategia como el arte de dirigir los conflictos armados. O como diría el general Beaufre el arte de la dialéctica de las voluntades que utilizan la fuerza para resolver el conflicto". Fue un tiempo de certezas. La estrategia era una disciplina militar y los grandes generales la re-definían según su talento. El Ejército era el modelo de Organización a seguir y la unidad de doctrina y de jerarquía eran los pilares de nuestra fuerza. En este esquema la comunicación jugaba un triple papel: la unidad de la voz de mando; la importancia del engaño; los símbolos y su poder psicológico. El paradigma cartesiano vino a convertir esas certezas en hechos predecibles. Nos aportó un universo mecánico, manipulable y predecible. Lo que nos condujo a la fragmentación, y al reduccionismo (Morin, 2003; Alberto Pérez y Massoni, 2009). A finales del XIX y principios del XX la teoría y los principios estratégicos elaborados en el ámbito militar se comienzan a aplicar a conflictos civiles sin violencia necesaria. La Estrategia se convierte en la Ciencia del conflicto. 
Pero al hacerlo lleva a confusión a muchos operadores haciéndoles creer que la vida es un campo de batalla y, a pensar que todo competidor u oponente es un enemigo. Un claro error a evitar.

h) El paradigma científico/matemático (1944/2011): Theory of Games and Economic Behavior de John von Neumann y Oskar Morgenstern fue una orientación revolucionaria para la toma de decisiones ante la incertidumbre estructurada. Ubica a la Estrategia en la Teoría de la Decisión y nos aporta un primer concepto científico de estrategia como: "El conjunto de las decisiones preparadas de antemano para el logro de un objetivo asignado, teniendo en cuenta todas las posibles reacciones del adversario y/o la naturaleza". La Estrategia es la suma de las tácticas y las tácticas paquetes de decisiones. Cuando con una única decisión se resuelve un problema, la estrategia se denomina pura, algo infrecuente en la vida real donde lo normal es que haya que combinar diferentes tácticas y estrategias, entonces la estrategia es mixta.

Encontramos aquí un elemento importante para nuestro discurso, pues nos dice que no todas las decisiones son estratégicas: una decisión solo es estratégica cuando en el cálculo que hace el decisor-para elegir entre una u otra alternativa de acción- tiene en cuenta la eventual participación de otros agentes (personas, fuerzas o sistemas) que con su intervención pueden modificar el resultado (Habermas, 1973; Alberto Pérez, 2001). Algo que tendremos que tener en cuenta pues si aplicamos este principio a la Comunicación resultaría que todas las comunicaciones serían estratégicas pues en todas se tiene en cuenta al receptor y sus posibles reacciones.

La teoría de los Juegos demostró su utilidad para los juegos simultáneos propios de la guerra fría y nos aportó conceptos e instrumentos de alto valor, entre ellos las estrategias dominantes y sus matrices de juego; los juegos de suma cero y de suma distinta de cero: los puntos Nash o de equilibrio; el dilema del prisionero, etc. Sería su pretensión de exactitud matemática la que terminaría limitando sus aplicaciones.

i) El paradigma económico/managerial (1954/2011): En 1954 Peter Drucker propone por primera vez el concepto de "decisión estratégica" en The Practice of Management, y un año después, en 1955, Harvard Business School dedica su Twentyfith National Business Conference a 
Planning the Future Strategy of your Business. La Estrategia entra así en las Business School. Sería Ronda (2002) quien, después de estudiar las 36 definiciones más comunes en el management del período 1962-2002, llegaría a concluir que se podrían agrupar en torno a tres concepciones:

- La Estrategia entendida como la herramienta de dirección que facilita la adaptación de la organización a los cambios del entorno.

- La Estrategia entendida como la vía para lograr el cumplimiento de metas organizacionales. Y como la disciplina científica que busca el éxito de las empresas.

- La Estrategia entendida en su sentido analógico militar como la forma de ganar a unos competidores que son vistos como enemigos.

Cuando en 1976 Igor Ansoff rebautizó al management de "estratégico" en su "Strategic Management", la Estrategia se impregnó de la racionalidad cartesiana: actores racionales; analistas estratégicos, etc. Tal vez por eso o por su origen económico al management estratégico tampoco le ha interesado la comunicación, solo la información, y hubo que esperar a los años 80 para que la comunicación entrase con fuerza en el management de la mano de la estrategia de diferenciación de Michael Porter $(1980,1985)$ y de los intangibles de Hiroyuki Itami y Thomas Roehl (1986). Se había producido la conexión entre la dirección estratégica y la comunicación. Una conexión que los comunicadores europeos sitúan como el segundo reto directivo según el European Communication Monitor 2010.

j) El escenario hoy (1990/ 2011): Seis datos lo describen:

1. Éxito: De la mano del management la Estrategia ha pasado a ocupar un lugar cada vez más destacado en los negocios, la política y la academia. Pero este momento de gloria no está exento de banalidad: se la presenta como la ciencia del éxito y se la vincula con fórmulas infalibles; los libros de Estrategia compiten con los de autoayuda en las librerías de los aeropuertos, a los profesores se les llama "gurúes" y Sun Tzu pasa a ser un icono de Hollywood. 
2. Fracasos: Los expertos denuncia que 5 de cada 7 estrategias fracasan, apenas un $56 \%$ de los nuevos productos alcanzan sus objetivos económico-financieros y el 90\% de los negocios nuevos cierran antes de 5 años. Datos que nos hablan de un verdadero fiasco y contrastan con la euforia anterior.

3. Críticas: El primer aviso lo da Philip Mirowski en 1989 con su "More Heat Than Light: Economics as Social Physics", pero sería 1994 el año de la primera ola de críticas: "The Rise and Fall of Strategic Planning", Henry Minztberg (1994); "The Death of Economics", Paul Ormerod (1994) y "Strategy as a field of Study: Why Search for a New Paradigm", Prahalad y Hamel (1994). La caja de Pandora se había abierto y ya nunca se cerraría. Se crítica el paradigma funcionalista; la rigidez de la planificación estratégica; la falta de ética; la desorientación del Management Estratégico; la pretensión de conocimiento y la debilidad teórica; el carácter elitista y la desvinculación entre estrategia y la práctica profesional de los altos ejecutivos.

4. Rectificaciones: En 1984 Tom Peters y Robert H. Waterman creyeron haber encontrado los 8 atributos de excelencia que caracterizan a las empresas sobresalientes. Y así lo hicieron saber al mundo en su best seller "In Search of Excellence". Un año después los datos vinieron a demostrar que aquellas 8 claves ya no eran las válidas e intentaron proponer otras. Tampoco funcionó. Cinco años más tardes en "Thriving in chaos" (1987) el propio Peters reconoció dignamente su error: "No existen compañías excelentes". Los atributos que ayer hicieron excelentes a una organización, la pueden hundir en un nuevo contexto.

5. Innovaciones: Otros expertos prefirieron aportar soluciones, entre ellas:

- Superar el enfoque conflictivo de la estrategia: Abierta la puerta por los juegos de suma distinta de cero y por "El Calculo del Consenso" del Nobel J. Buchanam, en los 80's surge una literatura más cooperativista y relacional: "Getting to Yes", Roger 
Fisher y William Ury (1991); “Coopetition”, Nalebuff y Branderburger (1997). Se habla de estrategias win-win.

- Introducir la conectividad: En los 90's se enfatiza desde distintos espacios el mundo en red, las redes sociales. La inteligencia pasa a ser conectiva en "The Skin of Culture" (1999) de Derrick de Kerkhoven.

- Superar la racionalidad: También en los 90’s el neurofisiólogo portugués Antonio Damasisio (Descartes' error, 1994) recupera el papel de las emociones en la toma de decisiones; una idea que divulga Daniel Goleman (Emotional Inteligence, 1995). No menos importantes los trabajos de Daniel Kanehmann que le valieron el Nobel de Economía en 2002.

- Incorporar las neurociencias: Encontramos tres intentos de multidisciplinariedad a través de la "Neuroecomía", fundada en 2001 por Kevin McCabe, Daniel Houser, Lee Ryan, Vernon Smith y Theodore Trouard; el "Neuromarketing" de Néstor Braidot (2005) y el "Neuropolitics" del profesor de lingüística de la Universidad de Berkeley, George Lakoff y su "The Political Mind" (2008) con sus metáforas, narrativas y marcos mentales.

- Incorporar la evolución y el caos: esta corriente surge (Laszlo y Lauger L'économie du chaos, 1998) como una herencia tardía del neo-evolucionismo cultural y antropológico de Leslie White y Julian Steward. Critica el paradigma clásico y denuncia que la innovación no se puede explicar desde el mecanicismo. En cambio, las propiedades de los sistemas complejos adaptativos permiten abordar la generación de ideas innovadoras.

- Conciliar los parámetros estratégicos con los objetivos empresariales: Una cuestión que se resolvería con el Balanced Scorecard de Kaplan y Norton (1992).

- El neo-institucionalismo: Basado en las propuestas del Premio Nobel de 1993 Douglass North. Su idea clave es que los miembros de una organización desarrollan creencias y significados 
(culturas), que ajustan las estructuras a sus necesidades. Una función que cumplen perfectamente las comunicaciones.

- El management narrativo: Frente a los modelos que abordan la comunicación como transmisión de información, los estudios culturales nos ayudan a entender la organización como generadora de sentido.

- The Cluetrain Manifesto (www.cluetrain.com): los mercados son conversaciones. Pérdida de diálogo entre las compañías y sus audiencias (Searls y Weinberger, 1999).

6. Los movimientos refundadores: En medio de estas propuestas innovadoras encontramos dos movimientos que en vez de parcheos y de cambios puntuales lo que hace falta es una verdadera refundación de la disciplina. Uno de ellos, el Foro Iberoamericano Sobre Estrategias de Comunicación (FISEC) pone el énfasis en la refundación de la Estrategia, el otro HMB lo pone en la refundación de la Dirección Estratégica (management).

- La Nueva Teoría Estratégica (NTE) 2001/2011: La primera vez que se plantea la necesidad de una nueva teoría estratégica es en 2001 en la página 672 del libro Estrategias de comunicación (Rafael Alberto Pérez): "Necesitamos una teoría estratégica menos geométrica y más hermenéutica, menos racional y más relacional". Reflexiones parecidas estaban presentes en otros expertos latinoamericanos: en Sandra Massoni: "La comunicación es un espacio estratégico en la dinámica sociocultural" (1990); en Jesús Martín-Barbero (2002) al sugerir la "posibilidad de que la comunicación sea un lugar estratégico desde el que pensar la sociedad"; en Marcelo Manucci (2004): "Diseñar estrategia es diseñar significados".

La propuesta conectó con expertos de diferentes países y dio lugar en 2003 al nacimiento de FISEC como una asociación sin ánimo de lucro que sirviese de plataforma de intercambio y debate. Actualmente tiene 485 miembros de 122 Universidades, y de unos 130 Medios de Comunicación, Instituciones y Empresas de 17 países de Iberoamérica más USA, Francia, 
Alemania, Italia y Rusia. Desde entonces FISEC ha realizado 8 encuentros internacionales elaborando y debatiendo esa nueva teoría. La respuesta se llama La Nueva Teoría Estratégi$c a$ (NTE) y se concreta en el libro Hacia una teoría general de la estrategia (Alberto Pérez, Massoni, 2009) Prologado por el Secretario General Iberoamericano, Enrique V. Iglesias: "Es esta una Teoría General de la Estrategia útil y abierta. Una nueva teoría para pasar del conflicto a la articulación, superar fronteras y lindes arbitrarios e incorporar visiones de conjunto tanto multilaterales como «transdisciplinares»". Lo importante para nosotros es que la NTE refunda la estrategia desde la comunicación. No es este el lugar para explicar la NTE, pero baste decir que propone 7 cambios con respecto a las formulaciones al uso:

1) En el paradigma: de la fragmentación a la complejidad.

2) En el sujeto: del actor racional al hombre relacional.

3) En la organización: de unidad de producción a nódulo de innovación y de significación.

4) En el objeto de estudio y en el enfoque: de lo contingente a lo inmanente y de ciencia del conflicto a ciencia de la articulación.

5) En la matriz de estudio: de la Economía a la Comunicación.

6) En el método: nuevas herramientas.

7) En la metodología: nuevos modelos.

La Estrategia que surge de esta refundación difiere sustancialmente de la teoría que todavía hoy se imparte en las Business School: la NTE es una teoría general de la estrategia y no solo militar o empresarial; trabaja desde un nuevo paradigma científico: la complejidad; tiene un nuevo sujeto: el ser humano relacional; mira las situaciones sociales desde una nueva perspectiva dialogante. Una teoría articuladora necesitaba un sistema de articulación y lo encuentra en la comunicación. Ya no se trata de una conexión: es toda una alianza.

- La segunda refundación: 2008/2011 Half Moon Bay: En 2007 Gary Hamel retoma la reflexión iniciada por el mismo y C.K. Prahalad en 1994 (ya citada) en su libro "The Future of Ma- 
nagement" cuyo primer capítulo lleva por título “ ¿El final del Management". Pero sería en 2008 cuando reunido en Half Moon Bay con un grupo de expertos provocase una refundación del management estratégico. La sintetizan en una proclama de 25 conclusiones (Hamel, 2009). En ella dan a conocer la gravedad de los fallos y desfases del management. Hubo coincidencia en el diagnóstico: el modelo de gestión que predomina en las grandes organizaciones está seriamente desfasado. Surgió en el siglo XIX para lograr que unos recursos humanos semi-cualificados, haciendo la misma cosa una y otra vez, llegasen a ser más efectivos. Es evidente que ese ya no es el reto para las compañías de hoy.

"Managers today face a new set of problems, products of a volatile and unforgiving environment. Some of the most critical (...) To successfully address these problems, executives and experts must first admit that they've reached the limits of Management - the industrial age paradigm built atop the principles of standardization, specialization, hierarchy, control, and primacy of shareholder interests. They must face the fact that tomorrow's business imperatives lie outside the performance envelope of today's bureaucracy-infused management practices" (Hamel, 2009).

Conscientes de las críticas que iban a provocar se autodenominaron "renegados": "A global community of management renegades brought together by Gary Hamel's Harvard Business Review article". Hoy día Hamel parece haber suavizado esas posiciones y nos dice que es el momento para "reinventar el management", mientras la Harvard Business Review crea una sección de "Reiventing your Business". 


\section{Conclusiones 2.1}

Es el momento de comprobar si esta incursión en el territorio de la Estrategia nos permite contestar a las preguntas que nos habíamos planteado en el inicio:

1. Respecto a la cuestión de qué Estrategia estamos hablando, hemos apreciado un fuerte desplazamiento semántico y conceptual desde el campo militar en el que la Estrategia se origina, para moverse hacia la vida civil en la política y la economía, para terminar aplicándose hoy a cualquier ámbito de la vida social. Hasta fechas muy recientes la noción ha cambiado en sentido, aunque no en dirección. Primero se enfatizó el uso (inteligente) de la fuerza -ganar al otro, la guerra- después, sería ganar al competidor. Y cuando al fin se enfatiza la inteligencia, la racionalidad toma el centro del pensamiento estratégico y lo tiñe de un fuerte cartesianismo, una situación que alcanza su plenitud en el management. En ese viaje, la noción elemental de Estrategia va tomado forma hasta sintetizarse en una fórmula sencilla y compleja: "Pensamiento para la acción eficaz en situación ante otros”. De ahí se desplaza de nuevo a otra fórmula; "Pensamiento anticipativo que nos permite elegir el camino hacia nuestras metas". Pero no es hasta la llegada de los proyectos refundadores cuando la Estrategia cambia no solo de sentido también de dirección y se replantea como una ciencia de la articulación. En ese contexto, la NTE nos propone una teoría general, abierta a todos los dominios de la acción humana y acorde con los nuevos paradigmas de la ciencia. Una teoría para la articulación social más que para el conflicto. La Estrategia así concebida es la disciplina que asiste a los hombres y mujeres de acción a reconfigurar su patrón de conectividad y a elegir el camino que mejor les ayude a alcanzar el futuro que desean. Y las "estrategias" (con minúscula) "el conjunto de elecciones (cauces de acción) que se adoptan en un momento concreto para alcanzar determinadas futuros (metas) teniendo en cuenta la intervención, real o potencial, de otras fuerzas, seres o sistemas".

2. Para que eso ocurriera la Estrategia tuvo que dejar de trabajar con constructos como el actor racional, el homo economicus, el jugador, etc. y recuperar al ser humano relacional. Esta encarnación de la Estrategia es la que va a permitir pasar de las teorías a la acción, de la acción a las prácticas profesionales y del conflicto a la articulación. Si se me permite parafrasear a Francisco Varela y su embody mind, yo diría que hoy estamos ante una embody strategy. Algo que ha pasado desapercibido para muchos pero que constituye, en mi opinión, uno de los rasgos más relevantes de esta enorme transformación que ha vivido la Estrategia. Es esa embody strategy, al tratar con seres humanos relacionales, la que permite entender 
el juego de complementariedades que la vida nos ofrece. Y nos plantea tal y como la ciencia y las humanidades nos muestran, que el mundo no sólo es depredación, es también, y sobre todo, colaboración, coordinación y cooperación. El concepto de Estrategia muta así en su sentido y su dirección. La conclusión a la que nos llevan estas reflexiones es clara. La sintetiza muy bien Jesús Galindo: Las responsabilidades sociales en general y ecológicas exigen un pensamiento y un método sobre la Estrategia más allá de la ganancia individual o particular. Un nuevo espacio con más dimensiones que las percibidas sólo desde el punto de vista de un ego individual, solitario y ambicioso. El pensamiento estratégico se enriquece por el contacto con la filosofía, con las ciencias sociales, con las ciencias exactas. Lo que partió de la guerra, de la Economía y la Política, tiene ahora otros temas en la agenda por desarrollar. El resultado de esta reflexión analítica es la imagen del tránsito del jugador racional al hombre jugador. De aquel que sólo juega para ganar, al que trata de entender todas las condiciones del juego para mejor jugar. Del actor individual o particular, frente a un entorno, una alteridad amenazante y coercitiva, al actor que interactúa y se relaciona con su entorno y con los otros, para convivir mejor con ellos. Parece que el concepto que completa la figura del hombre jugador es la comunicación, visión emergente a partir de la imagen de las partidas en el nuevo concepto de juego complejo, interactivo y co-participativo (Galindo, 2011).

3. Respecto a si todas las estrategias son comunicativas, qué son las estrategias de comunicación y qué son las estrategias cuando no son comunicativas, son cuestiones que apenas han sido tratadas por los expertos y sobre las que hay escasa literatura. No puede extrañarnos si tenemos en cuenta que, en los últimos años, la mayoría de los libros sobre Estrategia se han escrito desde el management y éstos no han tenido en cuenta a la comunicación, sólo a la información (Moss y Warnaby, 1998). Pero si nos fijamos en la letra pequeña veremos que las estrategias suelen ser clasificadas en función de sus metas (estrategia financiera, dietética; publicitaria); de su perfil de ruta (estrategia adaptativa, estrategia cíclica) y de sus principales elementos (comunicativos, gastronómicos). En este sentido, se suele hablar de estrategias de comunicación cuando el objetivo es comunicativo (por ejemplo alcanzar un $40 \%$ de conocimiento) y, finalmente, cuando la comunicación es el único elemento o el elemento principal de su mix (una campaña de publicidad). Así concebidas las estrategias de comunicación serían una parte o un a subcategoría de las estrategias. Se hace evidente, pues, que no todas las estrategias son comunicativas. Y que cuando no lo son, pueden serlo de otras muchas cosas como: estrategias sanitarias, de tráfico, gastronómica, etc.

Mediaciones Sociales, № 10, I semestre 2012, pp. 121-196. ISSN electrónico: 1989-0494. DOI: http://dx.doi.org/10.5209/rev_MESO.2012.n10.39684 
4. Y finalmente, respecto al adjetivo "estratégico" y qué cualidades traslada al sustantivo al que califica, hoy podemos decir que una acción se considera "estratégica" cuando cumpla al menos ciertos rasgos. Estos rasgos han variado a lo largo del tiempo, pero si nos fijamos en sus constantes encontraremos al menos cinco: (a) que haya sido concebida para alcanzar una determinada meta o escenario futuro; (b) que en su elección el sujeto haya actuado anticipativamente; (c) que se haya tenido en cuenta las reacciones y decisiones de terceras personas; (d) que se hayan evaluado las diversas rutas alternativas que supuestamente conducen a ese futuro deseado, y (e) que se haya elegido una. Si además trabajamos dentro de los nuevos paradigmas, entonces tendría que tener otros rasgos adicionales: reconfiguración del patrón de conectividad, articulación de percepciones, encuentro, emergencias, etc. Pero no por ser estratégica sino por ser sensible a los nuevos paradigmas.

\subsection{La jungla de la comunicación}

"FISEC y la Nueva Teoría Estratégica hacen la aplicación de la Complejidad a la Comunicación (y a la Estrategia). Yo lo he hecho en sentido inverso: la aplicación de la Comunicación a la Complejidad".

Edgar Morin

La Comunicación es el otro fenómeno que acota nuestro objeto de estudio y la segunda jungla que vamos a recorrer y analizar. De la Comunicación nos va a interesar aquí su relación y conexiones con la Estrategia: en qué sentido puede ser calificada de “estratégica”.

- El origen del fenómeno: Al igual que la Estrategia, la Comunicación es una capacidad de los seres vivos. El fenómeno comunicativo es tan antiguo y común como la vida misma. "Ser ya es comunicarse” (Borden, 1974). Común e inevitable, pues aunque quisiéramos, no podríamos dejar de comunicarnos (Watzlawick, 1997). El hecho de que la interacción comunicativa tenga un mejor balance energético que la física e incremente la capacidad de supervivencia puede ser la explicación de que en la historia de la humanidad haya habido un desplazamiento de actos físicos a actos comunicativos.

Mediaciones Sociales, № 10, I semestre 2012, pp. 121-196. ISSN electrónico: 1989-0494.

DOI: http://dx.doi.org/10.5209/rev_MESO.2012.n10.39684 
Algo que aprendí (Alberto Pérez, 2001) de Manuel Martín Serrano (1981) y que ahora el psicólogo de Harvard Esteve Pinker viene a confirmar con sus tesis de que la agresividad tiende a desaparecer del comportamiento humano (2009). "Vivimos en un mundo cada vez más empático", añade Punset (2011). Lo extraño es, que salvo excepciones, no merecieron el interés de los estudiosos de la comunicación.

- Dimensiones: Al estudiar la Comunicación hemos de diferenciar entre: Comunicación (con mayúscula): la disciplina y la categoría académica; comunicar: el proceso interactivo relacional; y comunicaciones (en plural y con minúscula): los actos expresivos en que se concreta el fenómeno. También aquí ha habido ambigüedad semántica y desplazamientos conceptuales según las épocas y autores.

- La palabra: Estamos ante un término tan fascinante como irritante. La palabra comunicación es una cajón de sastre donde cabe de todo: coches, trenes, teléfonos, cadenas de televisión, y hasta... delfines, pues hoy sabemos gracias Lorenz, Tinbergen y Von Frisch que los animales también se comunican (Alberto Pérez, 2001; Galindo Cáceres, 2005). Demasiadas cosas para una sola palabra, por ello no está de más rastrear su origen. Los griegos empleaban anakoinoum (tener algo en común); los romanos impertire (dar una parte a alguien). El actual vocablo comunicación viene del latín communicatio-communicationes, de significado similar al actual en castellano. Tanto el sustantivo communicatio como el verbo communico tienen su origen en el término commúnis, palabra formada por cum (con) y del tema munia (deberes, vínculos). Este último (raíz ma, ceñir) genera en latín otras palabras de similar expresión en torno al concepto de "unir juntamente", así moenia, los muros que encierran la ciudad, de donde viene moenir, fortificar. De esta forma en el propio origen del término comunicación se encierran las ideas de integración (crear vínculos comunes) y de la esfera pública en que se generan (la ciudad) y a la cual fortalecen. Pero, como Aranguren (1967) matizaría; si bien la palabra comunicación significa "puesta en común", la ciencia de la comunicación la toma en el sentido más restringido de "comunicación de mensajes" (Moles, 1982). Sería en Estados Unidos donde el término comenzase a designar la prensa, la radio, el cine y la televisión como medios de comunicación.

- El concepto: Tampoco aquí las cosas mejoran. Ya Thayer (1936) se refirió en su día a veinticinco diferentes concepciones del término comunicación y

Mediaciones Sociales, № 10, I semestre 2012, pp. 121-196. ISSN electrónico: 1989-0494. DOI: http://dx.doi.org/10.5209/rev_MESO.2012.n10.39684 
Bettinghaus (1966) ha llegado a recoger más de cincuenta descripciones diferentes de su proceso. Muchas de estas divergencias se deben, en gran medida, al carácter multidisciplinar de su estudio y, en consecuencia, a las diferentes aproximaciones y enfoques que han marcado la mirada de los autores que se han interesado por ella (Fauconier, 1975). Otras divergencias se deben al carácter multi-funcional de una Comunicación. En la medida en que la comunicación sirve para cumplir múltiples funciones: cohesionar, educar, informar, persuadir, seducir, motivar, etc. ha dominado hasta fechas recientes un enfoque instrumental de la comunicación. Además hay una tendencia de adjetivar la comunicación de persuasiva, propagandística, educativa, política, pública o de... estratégica y, de estudiar esos aspectos por separado sin que a los autores les preocupe en exceso si se trata o no de categorías conceptuales debidamente delimitadas. En todo caso habría que esperar a la primera mitad del siglo XX para encontrar las primeras teorías y concepciones científicas.

- La literatura: $\mathrm{Al}$ igual que ocurrió con la Estrategia, los primeros textos sobre Comunicación datan del siglo $\mathrm{V}$ a.c. Y todo indica que la retórica nació en Sicilia en el siglo V. a.c. con el texto de Corax de Siracusa (476 a.C.) que se considera fundacional, se orienta a ayudar a los ciudadanos ordinarios a defender sus demandas en los tribunales ${ }^{2}$. La verdad que no es creíble, difícilmente es aceptada. Para Corax, el objeto de la retórica es la argumentación y, su principio básico, la verosimilitud y la probabilidad. Junto a esta retórica de la verosimilitud, Empédocles de Agrigento (493433 a.C.) desarrolló, también en Sicilia, otra retórica psicagógica o conductora de almas relacionada con la medicina y con la magia. Desde Sicilia la retórica es llevada a Atenas por Tisias, discípulo de Corax, y por Gorgias. Es así como la retórica pasa a ser patrimonio de los sofistas. Un término que se aplicaba a los profesores que enseñaban el nuevo saber: la literatura, la ciencia, la filosofía y, especialmente, la oratoria. Ellos fueron los primeros humanistas. Y si hoy sofista es un término peyorativo se debe a que Platón les acusó de preocuparse más por la persuasión que la verdad. Un temor al poder de la comunicación que llega hasta nuestros días.

2 Los tiranos de Siracusa, Gelón y Hierón habían llevado a cabo expropiaciones masivas. Tras los alzamientos de Agrigento y Siracusa se estableció una forma de democracia y se iniciaron múltiples procesos para devolver las propiedades confiscadas (Hernández Guerrero y García Tejera, 1994).

Mediaciones Sociales, № 10, I semestre 2012, pp. 121-196. ISSN electrónico: 1989-0494. DOI: http://dx.doi.org/10.5209/rev_MESO.2012.n10.39684 
Liderados por la retórica, después por la propaganda, y más tarde por el conjunto de disciplinas de ellas derivadas, el trivium, el cuatrivium (3 de sus 7 artes eran comunicativas: la gramática, la dialéctica" y la retórica) y el ars predicandi, etc. encontramos toda una larga genealogía que conducen los estudios sobre Comunicación hasta nuestros días. Habría que esperar a 1949 con The Mathematical Theory of Communications de Shannon y Weaver para tener una primera concepción científica de la comunicación como "el proceso de transmisión de información". Hemos llegado así a la segunda mitad del siglo XX y los estudios sobre comunicación se mueven entre dos tendencias de signo opuesto: una convergente y la otra divergente:

a) Convergencia: Lo tardío de su estudio se ha visto compensado por una intensidad inusual. El siglo XX se ha caracterizado, en el ámbito de las ciencias sociales, por una intensa reflexión sobre el lenguaje. Es el famoso giro lingüístico. A través de él la sociedad pasó de ser vista como un conjunto de cosas, a concebirse como un conjunto de comunicaciones, una realidad concebida como generadora de sentido. Se produce así una fuerte convergencia de diversas disciplinas científicas sobre el fenómeno comunicacional. Se da la circunstancia que el científico que mejor supo explicar la íntima conexión entre la comunicación y el pensamiento humano fue un psicólogo: Vygotski. El que terminó de ubicarla entre el cuerpo y la mente fue un neurofisiólogo, el portugués Damasio, en su "Error de Descartes". El que nos aportó su primera formulación/definición científica, un matemático: Shannon. El que mejor relacionó comunicación y herencia cultural, un ingeniero: Korzybski, el padre de la semántica general, con su idea germinal del "time-binded". Uno de los primeros que relacionó comunicación con reglas y actos sociales, un antropólogo: Huizinga y su homo ludens; el segundo, un filósofo analítico: Wittgenstein, y sus juegos de lengua$j e$. El que mejor ha relacionado comunicación con capacidad simbólica, cultura y humanidad, un filósofo e historiador, Cassirer, el padre del homo simbolicus. El que mejor ha relacionado comunicación con evolución y conocimiento, un neurobiólogo, el chileno Maturana, padre de la biología del conocimiento. ¿Quieren que sigamos...?

Bueno, la conclusión es bastante elemental: o bien la comunicación no es cosa de comunicadores o bien los comunicadores necesitan avanzar transdisciplinarmente integrando en su visión unificada las diferentes ciencias y disciplinas que aportan lecturas complementarias de ese fenómeno que

Mediaciones Sociales, № 10, I semestre 2012, pp. 121-196. ISSN electrónico: 1989-0494. DOI: http://dx.doi.org/10.5209/rev_MESO.2012.n10.39684 
llamamos comunicación (Alberto Pérez, 2004d; Alberto Pérez y Massoni, 2009). Un camino con algunos sobresaltos.

Ya en los sesenta Wilbur Schramm en su obra Investigación de la comunicación en Estados Unidos (1965) enfatiza ambos hechos: la convergencia multidisciplinar y la decepción subsiguiente:

"La teoría y la investigación de la comunicación han atraído el interés de psicólogos, antropólogos, estadistas, economistas matemáticos, historiadores y lingüistas; los hombres dedicados a estas disciplinas científicas y a otros campos han contribuido a la comprensión de la comunicación. Es una encrucijada por la que muchos han pasado, pero en la que pocos se han detenido".

Frankling H. Knower (1966) cita más de veinte disciplinas académicas que proveen contenidos y métodos de investigación en alguna fase del proceso comunicativo. Y Lotman (1998) llega a sostener que es, en el campo de las ciencias de la comunicación a través de las matemáticas, la teoría de la información, la cibernética etc., donde se puede llegar a superar la contraposición decimonónica entre ciencias exactas y ciencias humanas.

Paralelamente a esta convergencia teórica se produjeron intentos de otra convergencia, esta vez para vincular la teoría con la práctica profesional (Múnera, 2010) Lo que llevó a unificar prácticas y oficios diversos con el fin de estructurar en los planes de estudio la capacitación de una profesión reconocida en el campo laboral (Macías y Cardona, 2007) En el caso español la primera Facultad -llamada de Ciencias de la Información y no de la Comunicación como en México- creada 1973 en la Universidad Complutense de Madrid, fue el resultado de refundir las Escuelas Oficiales de Periodismo (de ahí el nombre de información), Publicidad y Cinematografía. Un intento que, por otra parte, no resolvió los problemas de fondo y menos aún el de la división entre el conocimiento práctico y el teórico.

b) Divergencia: Los desplazamientos hacia un campo unificado que acabamos de citar no deben hacernos olvidar que esas distintas tentativas y ensayos no han pasado de ser eso: intentos. $\mathrm{Y}$ aunque en un momento se habló de la Teoría de la Comunicación hoy se prefiere hablar de teorías en plural. Ya en los 70’s, partiendo de una distinción clásica (Morris, 1938; Carnap, 1942) se hablaba de tres grandes corrientes: sintáctica, semántica y pragmática con sus respectivas conceptualizaciones.

Mediaciones Sociales, № 10, I semestre 2012, pp. 121-196. ISSN electrónico: 1989-0494.

DOI: http://dx.doi.org/10.5209/rev_MESO.2012.n10.39684 
- Para la corriente sintáctica derivada de la Teoría de la Información, la comunicación es un “proceso” y la información una “medida”.

- Para la corriente semántica la comunicación no sólo transmite nuevos datos (informaciones) sobre el entorno, sino que les da un sentido y un significado. Nos habla así de la sociedad como un espacio cultural y semiótico y del hombre como intérprete y constructor de su propia realidad.

- Para la corriente pragmática derivada del giro retórico la comunicación es una forma de acción: la acción comunicativa.

Pronto a esta lista corta habría que añadir las corrientes funcionalista (Laswell); conductista (Watson); estructuralista (Jakobson; Levi-Strauss); antropológica e interaccionista (Margaret Mead, Watzlawick, Palo Alto), sin olvidar los estudios culturales (Escuela de Birminghan); la teoría crítica (Horkheimer, Adorno; Marcuse); la acción comunicativa (Habermas); la intermediación (Martín Serrano, Martín-Barbero); la sistémica significativa (Luhmann) y la producción de sentido y el constructivismo (Berger y Luckmann) (Véase, Wolf, 1987). A ello habría que añadir aquellos abordajes más caracterizados por las posiciones ideológicas de los investigadores, que por las propias exigencias epistemológicas: pragmáticos, humanistas, analistas sociales, críticos de corte marxista, utópicos, e incluso pragmáticos utópicos, etc. Sin olvidar los estudios de la comunicación relacionadas con el poder, desde las visiones más filosóficas de Baudrillard; Bourdieu y Foucault hasta las más pragmáticas del marketing político (Maarek, 1995; Luque, 1996 y tantos otros). También habría que citar aquellos autores que estudian el impacto de las nuevas tecnologías de la información desde MacLuhan hasta Octavio Islas, pasando por un Manuel Castells que abandonó la confrontación urbana de corte marxista desde sus primeros trabajos por un mundo en red.

Ante esta situación surgen las voces que denuncian la carencia de un marco disciplinario que de sustento al estudio de la Comunicación. Un problema que ya estaba presente en CIESPAL (Costa Rica, 1973) y Manuel Martín Serrano en 1982: "La teoría de la comunicación tiene la tarea de integrar en un mismo modelo explicativo un sistema en el que rigen leyes físicas y biológicas, construcciones sociales y axiológicas”.

Mediaciones Sociales, № 10, I semestre 2012, pp. 121-196. ISSN electrónico: 1989-0494.

DOI: http://dx.doi.org/10.5209/rev_MESO.2012.n10.39684 
- El escenario hoy (1990/ 2011): ¿Qué ha quedado de tanta efervescencia? ¿Qué rasgos describen el escenario actual? Me permitiría decir que 6:

1. El problema epistemológico se ha hecho evidente pero continúa presente: Las tensiones entre una voluntad de convergencia y unas corrientes enrocadas en sus divergencias ha hecho que, a día de hoy, no dispongamos de un marco disciplinario que dé sustento al estudio de la Comunicación. Pero como destaca Sánchez Ruiz (2003), "si bien no hay disciplina, sí hay campo de estudio aunque más sociológico que epistemológico" pues tenemos ahí fuera objetos de estudio (la comunicación social, los medios, etc.) y una comunidad que se interesa. Yo me quedaría con esa última frase: hoy hay una comunidad que ha tomado consciencia del problema.

Este es el caso de Brasil (Intercom, Sociedade Brasileira de Estudos Interdisciplinares da Comunicação; Vassallo de Lopes, 2002; Marques de Melo, 2002 ; Margarida Kunch, 2003); en Argentina (Rivera,1987, 1997; Follari, 2000); en Chile (V Congreso Lationamericano de ALAIC, 2000); en Bolivia (Luis Ramiro Beltrán, 2000); en Venezuela (Mato, 2001); en Colombia (Martín-Barbero, 2003; Antonio Roveda (2007, 2008, 2009 ) y en México (Fuentes Navarro, 1989, 1992; Sánchez Ruiz, 1989; Guillermo Orozco Gómez, 1995 y Galindo Cáceres (1995; 2005); Carlos Luna (1995); Torrico, (1999) Norma Macías, Diana Cardona $(2007)^{3}$.

Es precisamente esa reconducción del "campo académico de la Comunicación hacia una reconstrucción reflexiva”, que lideran los movimientos de la comunicología, el GUCOM, REDECOM y la Comunicometodología, los que nos conducen hasta esta VIII Bienal Iberoamericano de Puebla. Aunque no nos engañemos, como Macías y Cardona (2007) comentan -y desde mi experiencia confirmo- es una cuestión que no parece preocupar excesivamente a nuestros colegas y en la que solo unos pocos se han comprometido. Es el caso de las citadas autoras y de Jesús Galindo, en México y de Antonio Roveda en Colombia.

3 Una lista que con seguridad está llena de ausencias no por demérito de sus autores sino por olvido o ignorancia mía.

Mediaciones Sociales, № 10, I semestre 2012, pp. 121-196. ISSN electrónico: 1989-0494. DOI: http://dx.doi.org/10.5209/rev_MESO.2012.n10.39684 
2. Arrastramos viejos esquemas y categorizaciones: No solo no hemos unificado el campo sino que aún convivimos con viejos fantasmas. Entre los que todavía sobreviven están: (a) la idea de que la comunicación es algo que un emisor hace a un receptor. Propio de la aproximación sintáctica heredada de la teoría de la información. Una teoría pensada para la transmisión de mensajes entre máquinas (telégrafo) y alejada del fenómeno esencialmente impreciso, contextual y social de la comunicación humana (Alberto Pérez y Massoni, 2009). Y (b) la vieja diferenciación entre comunicación informativa y persuasiva. A pesar de los meritorios esfuerzos de Katleen K. Reardon (1981) por redefinir la persuasión se trata de una dicotomía que entendemos inconsistente. Desde una visión compleja toda comunicación es informativa y persuasiva a la vez.

3. La visión que emerge de los nuevos paradigmas se está afianzando: A pesar de las inercias y de las resistencias, los estudios comunicacionales se están desarrollado en estos últimos 20 años en una dirección que rebasa los paradigmas clásicos. Tres corrientes merecen especialmente nuestro interés:

- Teorías de la reducción de la incertidumbre: La teoría de la reducción de la incertidumbre que sostienen Charles Berger y Richard Calabrese (1975) propone que cuando dos extraños se encuentran, su principal preocupación es reducir la incertidumbre o acrecentar la predictibilidad de sus conductas y la de los demás en la interacción. Feffer (1970) explica que esto sirve también para generar anticipaciones de la respuesta del otro a una acción proyectada. La certidumbre la obtendría el observador por inferencia y en ese sentido viene a coincidir con el principio deductivo de Kelly (1955), quien nos dice que las personas "se dedican a la predicción". Por su parte los teóricos de las normas (Pearce y Cronen, 1978; Cushman, 1977; Reardon-Boyton, 1978; Shimanoff, 1980) han propuesto que la gente desarrolla esquemas cognitivos que perciben y/o describen lo que "debiera" ocurrir en las interacciones. Lo que significa que en nuestra comunicación interviene en gran medida una anticipación y una planificación consciente. 
Cronen y Pearce (1978) parten del supuesto de que la gente pacta una con otra para generar episodios determinados de comunicación. Cada persona supone que comparte con los demás participantes del acto comunicativo una compresión de lo que previsiblemente puede ocurrir y un acuerdo tácito en cuanto a la no transgresión de esas expectativas. De modo que, las normas del consenso constituyen un prerrequisito esencial de la coordinación del significado. Una concepción de la comunicación que nos lleva a la ingeniería del consenso de Bernays (1955) y que nos remite a la noción de juego cooperativo.

- Constructivismo: De acuerdo con el antiguo paradigma, el lenguaje no sería otra cosa que un instrumento que nos permite "describir" lo que percibimos (el mundo exterior) o "expresar" lo que pensamos o sentimos (nuestro mundo interior). Esta concepción convertía el lenguaje en una capacidad fundamentalmente pasiva o descriptiva. Se asumía que la realidad antecedía al lenguaje y éste se limitaba a "dar cuenta" de ella. Pero hoy ya no pensamos así. A partir de Thougt and Language de Vygostki (1934), pero sobre todo a partir del giro lingüístico operado por pensadores como Wittgenstein, Heidegger y Maturana, hoy se han invertido las relaciones entre lenguaje y pensamiento. Según el nuevo paradigma, el pensar discurre por los surcos abiertos por el habla. Y los neurocognitivos nos dicen que el lenguaje juega un papel fundamental en todo el proceso perceptivo, ya que determina la experiencia que tiene el individuo (y su comunidad) del "mundo real". Una idea que ya encontramos en Benjamín Lee Whorf para quien las estructuras lingüísticas determinan lo que el individuo percibe del universo y cómo lo piensa (citado por Steiner). Y es a través de un mecanismo de "re-construcción lingüística" como logramos el acceso a fenómenos no lingüísticos (Moriello, 2005). "Lo social, para los seres humanos, se constituye en el lenguaje. Todo fenómeno social es siempre un fenómeno lingüistico" (Echeverría, 2004). De ahí la no-neutralidad del lenguaje (de la que hablábamos hace un momento con respecto a la comunicación informativa y persuasiva) o lo que es igual, la noneutralidad de la red de significados y sentidos por medio de la cual construimos nuestro mundo. Todas estas propuestas de comprensión del mundo a partir del lenguaje implican ver los fenómenos sociales de dos formas básicas: uno como expresión de una estruc- 
tura lingüística que enmarca y constriñe sus elecciones de sentido, y otro como experiencia vital de un sujeto activo, capaz de proponer el mundo mismo y proponer su visión del mundo desde su cotidianidad única e irrepetible. Unas ideas que han defendido con contundencia y talento Francisco Varela y Rafael Echeverría.

- Interaccionismo: Hoy se entiende la comunicación social como un proceso de interacción macrosocial (J. Ibáñez, 1990; R. Penman, 1980; S. Massoni, 1990); se amplía así la mirada que estaba ciertamente centrada en los mensajes y se comienza a examinar a la comunicación como un circuito espacio/temporal de acaecimientos vinculados que involucran a personas que se encuentran en el campo perceptual del otro, personas en interacción. Este enfoque deriva en una reconceptualización de la comunicación que destaca su dimensión como proceso en el marco de lo fluido (Massoni, 2007, 2009), en tanto considera los acoplamientos dinámicos y evolutivos de la realidad y los sujetos. La comunicación como espacio de encuentro de la heterogeneidad sociocultural (Massoni, 1990, 2007) y como sistema de articulación de percepciones plurales desde el que podemos dar nuevas configuraciones a nuestra trama relacional (Alberto Pérez, 2001, 2007, 2009). Estamos hablando de pasar de una comunicación lineal a una comunicación compleja. De una plana a otra multidimensional. De la comunicación como proceso informativo a la comunicación como lugar de encuentro, hibridación y transformación en donde se articulan las percepciones plurales de la realidad. Como destaca Sandra Massoni la buena nueva es que la redefinición de la comunicación a partir de la interacción y el encuentro implica entender que no hay un narrador centrado, como tampoco hay un mundo interior y otro exterior, sino el acaecimiento de acciones y sentidos compartidos por quienes se ponen en contacto al comunicarse (Alberto Pérez y Massoni, 2009).

4. Emerge un nuevo sujeto que hace y se hace en el juego comunicativo: Como resultados de estos procesos, hoy no solo podemos hablar de una embody strategy sino también una embody communication. Hasta ahora, emisor y receptor eran roles, no personas. Y algunos estudiosos de la comunicación atrincherados en posiciones ideológicas han mirado con recelo al emisor, un ser que supuestamente usa su saber 
comunicativo para manipular, al tiempo que han pretendido proteger y advertir al receptor de los riesgos que corría con manipulaciones culturales, políticas o comerciales, Haciéndole pasar por el bueno de la película, sin darse cuenta de la complicidad real entre las audiencias y los medios. El final de esa historia es bien conocido: ni el receptor era el bueno ni el emisor el malo, ni prejuzgar es científico. Nuestro papel es estudiar el fenómeno (eso si, sin renunciar a nuestras propias posiciones éticas) y retornar el resultado de nuestras investigaciones a la sociedad para que tome sus propias decisiones. Afortunadamente hoy los académicos no solo se acercan a los sujetos de la comunicación de una manera más neutral si no que además los integran en el fenómeno comunicativo. Así el chileno Rafael Echeverría nos da tres aportes fundamentales:

- Los seres humanos son seres lingüísticos: Seres que viven en el lenguaje. El lenguaje es lo que hace a los seres humanos el tipo particular de seres que son.

- El lenguaje es generativo: No solo describe y expresa el mundo exterior, sino que además es generativo: crea realidades y modela nuestra identidad, nuestro futuro y el mundo en que vivimos. La filosofía del lenguaje nos enseña hoy que el lenguaje es acción y crea realidades: hace que sucedan cosas. Y por medio de él participamos en el proceso continuo del devenir.

- Los seres humanos se crean a sí mismos en el lenguaje: Echeverría afirma que "el individuo no puede ser separado de su relato. El relato es constitutivo de lo que el individuo es". Algo que tristemente parece confirmar el mal de Alzheimer. Sin memoria, sin relato, es decir sin pasado y sin proyecto de futuro, los humanos dejamos de ser para meramente estar. "Ser humano es estar en un proceso permanente de devenir, de inventarnos y reinventarnos dentro de una deriva histórica. Un espacio abierto apuntando al futuro". Sin duda, una propuesta de claras implicaciones estratégicas.

5. El despegue de los estudios sobre comunicación organizacional: Es sabido que los grandes proyectos y las grandes estrategias raras veces son la obra de un hombre solo, sino que suelen ser el diseño de un sujeto colectivo llamado organización. Las organizaciones son hoy el gran suje- 
to de la comunicación y la acción pública. Los negocios, la política y el marketing (pero también la educación, la sanidad, e incluso la fiscalidad etc.) son procesos de intercambio manejados por organizaciones y una parte de esos intercambios son simbólicos, es decir, comunicativos. Una toma de conciencia que produjo el despegue de los estudios sobre comunicación corporativa/organizacional. Un nuevo escenario que se describe muy bien en "Interfaces e tendencias da comunicaçâo no contexto das organziaçôes" de Ivone Lourdes de Oliveira y Ana Theresa Nogueira Soares (2008).

"Nesse ceáro, a gestâo da comunicacçâo nas organizaçôes pautada no paradigma clásico/informacional, centrado na emissaâo e recepçâo de infromaçôe s, torna-se insuficiente para administar a abundancia dos fluxos e demandas informacionais e acrescente rede de relacionamientos que se establece entre organiçâo e actores sociais” (Oliveira y De Paula, 2008).

Al tiempo, las organizaciones cambian el viejo paradigma piramidal y jerárquico por otro plano, sistémico, conectivo y significativo, lo que les lleva a poner el énfasis en la comunicación, ya no para persuadir sino para dirigir. La comunicación pasa así a ser clave para conectar las inteligencias existentes en el seno de una organización (Derrick de Kerkhoven, 1997) y para manejar los interfaces con el entorno. De esta forma se subraya la necesidad de fomentar la comunicación para interconectar las aportaciones de cada componente y provocar sinergias entre ellos. La comunicación pasa así a ocupar un papel constituyente y no meramente instrumental. De ahí el énfasis que autores como Levi-Strauss y Castoriadis; Maturana y Varela; Luhmann, y Greenfied han puesto en la importancia de la conversación y la construcción social de los significados.

Sí entendemos a las organizaciones como entes vivos que se autotransforman y, a los organismos vivos como sistemas autopoiéticos (Maturana y Varela, 1981), entonces la pregunta pasa a ser: ¿qué producen las organizaciones? Una pregunta que encontraría su respuesta en Luhmann: significación.

- La comunicación es el dispositivo fundamental de la configuración y de la dinámica de los sistemas sociales. 
- Los sistemas sociales siempre se forman a través de la comunicación.

- Los sistemas sociales se autoconfiguran mediante un doble proceso: diferenciación e identidad.

- La comunicación es vital para el sistema social.

Una idea que ya estaba en el primer Baudrillard, cuando dijo que la realidad era un sistema de símbolos superpuestos a un sistema de objetos. Y en Marcelo Manucci que nos propone "trabajar la comunicación como la gestión de significados". La generación de sentido, se convierte así en la gran estrategia que debe guiar a una organización. La tarea directiva consistirá en saber establecer qué sentido y qué significación ha de generar una organización. No nos puede sorprender que uno de los temas centrales del I Congreso Iberoamericano de Comunicación Organizacional (CIESPAL, Quito, 2003) fuese precisamente la necesidad de elaborar y ejecutar estrategias en las organizaciones y que el mexicano Rafael Ávila (2004) proponga una "reconstrucción disciplinaria”.

6. Internet y las redes sociales: los avances en la tecnología digital están permitiendo transformaciones que van más allá de lo estrictamente tecnológico, como la incorporación del feed back. Pero es una temática que solo voy a enunciar. La tratará pasado mañana el profesor Fernando Gutiérrez con el rigor que el tema se merece. Y será a él a quien haya que escuchar. Tan solo la cito aquí para decir que forma parte del nuevo escenario y para compartir unas palabras de otro ponente (que hablará mañana) Sandra Massoni cuando dice que con Internet la comunicación es un fenómeno más complejo; hace que la acción comunicativa se desplace desde el mensaje hacia el vínculo; y nos pone no en un espacio sino en una intersección: en redes fluidas y contingentes (podcast Dircom 2010). 


\section{Conclusiones 2.2}

1. Después de este paseo por otros XXV siglos de pensamiento, esta vez siguiendo los senderos de la comunicación, hemos encontrado muchas similitudes con lo ocurrido en el campo de la Estrategia. También la comunicación ha tenido varias agendas a lo largo del tiempo, casi todas asociadas con la persuasión y el control. Pero en paralelo, otra corriente nos habla de coordinación, cooperación y negociación. De este contexto dialéctico surge un proyecto colectivo de construcción de una Ingeniería en Comunicación Social. La TNE de FISEC es parte de este movimiento hacia posiciones dialogantes.

2. Respecto a la cuestión que nos planteábamos al inicio de este trabajo de qué es Comunicación, hemos de decir que también la Comunicación sale transformada de su baño en los nuevos paradigmas. Al igual que la Estrategia, la Comunicación también se ha encarnado (embody communication) y ha dejado de ser instrumental para ser constituyente de nuestra humanidad, pero también de nuestra trama vital. Deja de ser transmisión para pasar a ser una categoría de la acción. Deja de ser algo que un emisor hace a un receptor para ser el espacio de encuentro de nuestro yo con su entorno, de construcción de nuestro mundo y de relación con nuestros semejantes. Deja de ser un sistema unidireccional para ser un sistema interactivo, relacional y social de hibridación y transformación entre las alteridades presentes en cada situación. Un sistema que nos permite generar significación conjunta, articular nuestras diferencias y configurar nuestra trama social presente y futura. Cuando se habla de la comunicación como el sistema en que los seres humanos se crean a sí mismos en su devenir, se está estableciendo una conexión clara con la Estrategia.

\subsection{La jungla de las intersecciones: la comunicación estratégica}

Al fin hemos llegado al lugar en que los senderos se encuentran después de muchos años de bifurcaciones: la comunicación estratégica. Y si en los recorridos anteriores ya hemos concretado de qué Estrategia y de que Comunicación estamos hablando, la pregunta ahora es qué significa realmente comunicación estratégica ¿Cómo podemos distinguir entre el uso estratégico de la comunicación y su uso "no estratégico"? 
Tenemos una solución fácil. Sabemos lo que es comunicación y sabemos lo que es estratégico: solo hay que juntarlo. Pero, pienso que elementos tan complejos como los que estamos tratando no se armonizan con una simple combinación de palabras. Tampoco es esa la metodología que hemos establecido. Lo que realmente nos corresponde ahora es revisar la literatura específica sobre comunicación estratégica y entender como otros -aquellos que han trabajado este campo- lo han entendido.

\section{- El origen del fenómeno:}

"La idea de que la estrategia es necesaria para la comunicación no es nueva: desde los primeros actos de propaganda política hasta nuestros días, pasando por la concepción aristotélica de la retórica, los hombres han intentado mejorar su posición relativa utilizando estrategias y métodos de comunicación. De hecho, todos estariamos de acuerdo en que, sin estrategia, nuestras palabras y demás actos comunicativos perderían gran parte de su eficacia, pues no basta transmitir lo que se piensa, sino también pensar lo que se transmite".

Son palabras del General Alonso Baquer (2001), uno de los autores que en España ha estudiado con mayor rigor la noción de estrategia desde sus múltiples acepciones. Pero si la comunicación estratégica existió desde siempre, sabemos que no podía llamarse así. Pues, como ya se ha dicho, hasta finales del XVIII la palabra estrategia ha tenido un sentido exclusivamente castrense y por comunicación estratégica se hubiese entendido, en el mejor de los casos, algún tipo de comunicación militar. Esa es la principal razón de que ambos términos, Estrategia y Comunicación hayan vivido vidas separadas. Hubo que esperar al Capítulo XII de "Scientific Advertising" (Hopkins, 1923) para que se vinculase por primera vez estrategia con comunicación, o más preciso con una de sus manifestaciones: la publicidad. La innovación de Hopkins fue apoyarse en la extensión analógica del paradigma militar de la estrategia y no en el retórico-persuasivo de la comunicación. En sus propias palabras: "Advertising is much like war, minus the venom. Or much, if you prefer, like a game of chess". Sin saberlo Hopkins había puesto los cimientos de una nueva categoría.

- Dimensiones: Todo indica que estamos ante un interfaz de dos capacidades humanas. Si vemos el fenómeno del lado de la Estrategia, esta recibe las cualidades articuladoras y significativas de la Comunicación y si lo vemos del lado de la Comunicación, esta se beneficia de las cualidades anti- 
cipativas y de cálculo ante terceros de la Estrategia. Dependiendo de qué disciplina proceda el investigador predominará una dimensión u otra.

- La expresión: Sus primeros usos fueron relativos a la publicidad. Se hablaba de Estrategias Publicitarias. Una expresión que rechinaba a la Academia. Harvard Univesity tiene que esperar a los años 60's para sustituir el término policy por strategy. Y recuerdo que por el año 1974/75 cuando impartía "Estrategia Publicitaria" en la Universidad Complutense de Madrid mis colegas me preguntaban jocosos si les iba a impartir clase a los alumnos o a darles la instrucción militar. Con el tiempo se abrió el foco y se comenzó a hablar de Estrategias de Comunicación y de comunicaciones estratégicas.

- El concepto: El espacio conceptual en que se ubica hoy la "comunicación estratégica" es el resultado de los desplazamientos de la Estrategia y de la Comunicación hacia los nuevos paradigmas. Pero también aquí encontramos diversas corrientes.

- La literatura: Aunque la conexión entre estrategia y publicidad se establece en 1923, hay que esperar varias décadas para que esta temática trascienda el ámbito de las revistas profesionales de publicidad y merezca algo más que una referencia en algún capítulo de libro. De hecho los primeros libros dedicados explícitamente a las Estrategias Publicitarias se publican a finales de los años 50's y hasta los 80's apenas superan la decena: "Advertising management" de Borden y Marshall (1959); "The strategy of Desire" de Dichter (1960); "Estrategias publicitarias" de Bogart (1967); "Elaboración del mensaje publicitario", de Cristóbal Marín (1971); "Estrategia publicitaria y de Marketing", de Audy (1973); "Advertising Management" de Aaker (1975); "La eficacia de la publicidad ante las actitudes de los consumidores" de Alberto Pérez y Suso (1977); "Estrategias publicitarias" de Alberto pérez y Martinez Ramos (1981); "Strategic Advertising Campaigns" (1979) y "Essentials of Advertising Strategy" (1981) de Schultz.

En la mayoría de estos textos la estrategia publicitaria es entendida como una idea rectora que da sentido al conjunto de acciones y de esta forma potencia el poder de la comunicación. Recuerdo que esta idea ya estaba 
presente en mi primer trabajo de investigación sobre estrategia ${ }^{4}$. En él, como complemento al estudio de documentación (desk information) se realizó una consulta internacional a expertos. Sus respuestas resultan significativas:

- "La estrategia publicitaria describe la visión global con que debe enfocarse la publicidad para alcanzar los objetivos asignados": Clay S. TIMON (Senior Vice President International, Doyle, Dane, Bernbach, New York).

- "La estrategia publicitaria es la guía de oro para alcanzar una meta": Prf. Dr. Wayne ALEXANDER (Department of Bussines Administration, "Moorhead University" Minnesota).

- "La estrategia publicitaria se refiere a la dirección y guía que debe utilizarse como columna vertebral para la formulación de tácticas publicitarias": Murray W. GROSS (Vice President, Grey Advertising, New York).

- "Una metodología para la comunicación y la persuasión": Information Manager (Denver Research Institute, Colorado).

"Visión global", "guía de oro" (blueprint), "columna vertebral", "métodos" y "metodología" son expresiones que ponen el énfasis en la capacidad de vertebración que la estrategia aporta a la acción publicitaria y comunicativa por extensión.

De la publicidad, la estrategia pasa a las relaciones públicas, un término generoso que en aquel contexto podría entenderse por comunicación corporativa. Se desarrolla una literatura sobre estrategias de las RRPP: $\mathrm{Cu}-$ tlip y Center, 1952; Gruning y Hunt (1984); Boyry (1989); Botan y Hazleton (1989); Wilcox, Cameron, Ault y Agee (1989); Kendall (1997); A. Arceo Vacas (1999), Steyn (2003). En ese contexto se habla de que los

4 En 1978 el Instituto Nacional de Publicidad, encomendó a la empresa Emopública la realización de un estudio sobre "Métodos para la realización de la estrategia publicitaria". La dirección de la investigación fue llevada a cabo conjuntamente por el profesor de "Estrategia de la publicidad y de las Relaciones Públicas" de la Universidad Complutense, y por el Director de Emopública, el también profesor Emilio Martínez Ramos. Una adaptación de dicha investigación fue publicada posteriormente por el Instituto nacional de Publicidad (Alberto Pérez y Martínez Ramos, 1981).

Mediaciones Sociales, № 10, I semestre 2012, pp. 121-196. ISSN electrónico: 1989-0494.

DOI: http://dx.doi.org/10.5209/rev_MESO.2012.n10.39684 
programas de comunicación deben ser gestionados estratégicamente si se quiere construir relaciones a largo plazo (Grunig and Repper 1992).

Los expertos argumentan que las relaciones públicas, y por extensión la comunicación, juegan un papel clave al ayudar a las organizaciones a escanear y diagnosticar sus entornos, manejar los roles externos representativos y a generar los intercambios entre los públicos externos (stakeholders) y las capacidades y competencias de la organización (Aldrich and Herker, 1977; Cutlip et al., 1994). Y, que esa función estratégica merece ser reconocida por un management que ha vivido de espaldas a la comunicación.

Despega así una tendencia a "estrategizar" las comunicaciones orientadas a fines de la que no se escapó ni la propaganda religiosa. Es el caso de Greinacher y su "Estrategia de una pastoral diocesana" y de la "Estrategia social de Jesús" de W. Kennedy.

Llegamos así a unos años 90's en los que el término estratégico aparece por doquier ligado a la comunicación. Y aunque en ese momento no se habían publicado trabajos de fondo que lo soportasen, todo indicaba ya que no se trataba de una tendencia pasajera y que la comunicación estratégica había venido para quedarse.

- El escenario hoy (1990/2011): El proceso es tan reciente que carecemos de la necesaria perspectiva. En todo caso destacamos 5 rasgos que merecen nuestra atención:

1. Triple convergencia: Aunque estamos lejos de la tan deseada unificación del campo, los esfuerzos no han sido en vano. Ya se ha hecho un largo camino. Los desplazamientos a los que venimos asistiendo han facilitado al menos tres convergencias:

- Una primera convergencia es teórica: Tanto la Estrategia y la Comunicación han cambiado y lo han hecho en la misma dirección que entendemos es la correcta: los nuevos paradigmas científicos y sociales. Eso hace que nunca la Comunicación haya sido tan estratégica ni la estrategia tan comunicativa. Pero eso no debería llevarnos a confundirlos. 
- Junto a esta convergencia en la mirada hay una segunda convergencia: la de los distintos sistemas de comunicación que en el seno de las organizaciones manejan las Direcciones de Comunicación: relaciones públicas, publicidad, newsletters, comunicación on line, diálogo en las redes sociales. Todos, sistemas que necesitaban estar interconectados mediante una estrategia global que los vertebrase alrededor de los objetivos de la organización. De ahí la idea de una comunicación estratégica integral organizacional.

- La organización se convierte así en el espacio de una tercera convergencia, la de las teorías académicas y la práctica profesional. Las organizaciones -en cuanto sujeto colectivo que son- incorporan profesionalmente y encarnan, en sus procesos de interacción internos y externos, ideas estratégicas generadas y/o impartidas en las Universidades. Algunas llegan a ponerse de moda entre los altos ejecutivos. Fue el caso de las matrices de Porter en los 90's.

2. Efervescencia: A partir de los 90's surge una literatura centrada en las estrategias de comunicación y en la comunicación estratégica. Véase: Caywwod, (1997); R. Kendall (1997); P. Capriotti (1999); Dolphin y Fan (2000); Alberto Pérez (2001); Tironi (2004) Manucci, (2004, 2005) Massoni (1990); Argenti, Howell y Beck (2005); De Salas (2005) Villegas (2006); Vasquez (2006) Scheinsohn (2009). Esta literatura germinal se ha ramificando en cuatro líneas de trabajo:

a. Comunicación estratégica organizacional: La necesidad de encarnar el nuevo enfoque termina ubicando la comunicación estratégica en la organización y es ahí donde se viene desarrollando con fuerza bajo la rúbrica de comunicación estratégica organizacional. Un fenómeno que es estudiado Por; Muriel y Rota (1980); Putnam y Pacanowsky (1983); Bartoli (1991); Conrad y Poole, 1994; Van Riel (1997); Schultz (2000); McPhee y Zaug (2000); Oliveira (2002); Cardoso (2002) ; Freitas (2002) ; Bueno (2003) ; Kunsch (2003); Ávila (2004); Marchiori (2006); May y Mumby (2006); Múnera (2007); Oliveira y De Paula (2008); Oliveira y Nogueira Soares (2008) y tantos otros.

b. La figura del DIRCOM: Para que la comunicación organizacional fuese estratégica, alguien tenía que gestionarla y ese alguien es el 
DIRCOM. Una figura profesional que surgió de la práctica profesional con tanta fuerza que, por sí misma, es ya un rasgo más del escenario que venimos comentando y que es objeto de reflexión escrita (Mut Camacho, 2006).

c. La comunicación estratégica política: la dimensión política de la Estrategia y de la Comunicación convierten al marketing político en un campo abonado para las estrategias de comunicación (Desde Edelman (1988) y Maarek (1997) hasta Lakoff (2003).

d. Las nuevas tecnologías de la información y como afectan a la sociedad (brecha digital, open access) y a las organizaciones (community manager y social media strategist): Octavio Isla (2003); Canella (2005); Pimienta y Barnola (2001); De Salas, (2005) y tantos otros.

3. Diferentes aproximaciones: A la hora de concretar cuáles son los rasgos que definen la comunicación estratégica encontramos tres posiciones diferenciadas:

- Aquellos que utilizan la expresión comunicación estratégica pero no se preocupan por explicar qué aporta a la comunicación dicho calificativo. Se limitan a poner "estratégica" donde antes decía "persuasiva" o no decía nada. Pareciera que con ello pretenden dar una idea más actual y moderna no tanto de la comunicación como de sí mismos.

- Otro grupo se preocupa por modernizar las organizaciones y hacerlas más estratégicas. Pero al seguir anclados en el paradigma racionalista del management clásico no introducen los cambios conceptuales que la nueva adjetivación se supone que exigiría:

a. "La estrategia de comunicación consiste en definir con claridad quiénes somos y qué ofrecemos. Nada más. Y nada menos.” Francisco Barranco.

b. "Estrategia de comunicación es la actividad que "describe cómo se va a alcanzar, en teoría, un objetivo, ofreciendo líneas directrices y temáticas para el programa global”. Wilcox y Ault. 
c. "La comunicación empresarial se hace estratégica en la medida en que se sabe dónde está y a dónde se quiere llegar, y para lograrlo se debe contar con una visión entrenada para analizar y comprender espacialmente aquello que rodea la empresa y las diferentes situaciones que vive", Italo Pizzolante Negrón.

d. "De todas las dimensiones del término "estrategia" la que mejor casa con el uso de la expresión "comunicación estratégica" es, sin lugar a dudas, la que lo define como "posición y ventaja”. Esta es la noción de estrategia, muy vinculada a su origen técnico-militar, que tenía en mente Michael Porter al formular en los años 80's sus teorías del Posicionamiento y de la Ventaja Competitiva. S.Sánchez Benítez (2011).

- Los que, ya viniendo del management y de la comunicación, acotan el fenómeno desde una lectura acorde a los nuevos paradigmas. Esta es la literatura que nos interesa y a la que hemos de acudir para identificar el fenómeno y orientar la acción comunicativa. Dentro de esta corriente detectamos tres subcorrientes:

A 1. Aquellos autores que no llegan a explicar el fenómeno pero subrayan, con acierto, algunas funciones y rasgos del mismo:

- "La comunicación estratégica debe ser entendida como un proceso participativo que permitirá trazar una línea de propósitos que determina el cómo se pretende lograr los objetivos". Felipe Nieves Cruz.

- "Una práctica que emerge con la maduración que experimenta el campo de las comunicaciones en la modernización de las sociedades cuyo objetivo es convertir el vínculo de las organizaciones con su entorno en una relación armoniosa y positiva desde el punto de sus intereses y objetivos (...) Su primer interés es el posicionamiento de la organización". Tironi y Cavallo. 
- "Se requiere de una comunicación planificada, que involucra el análisis de entornos, de riesgos y de amenazas, que permitan la generación de un diagnóstico acertado y asertivo para calar con una visión estratégica empresarial que estampe la diferencia en dicho entorno". Katia Muñoz Vásquez.

- "La gestión estratégica de las comunicaciones empresarias, es decididamente holística, total e integradora”. Joan Costa.

A2. Una segunda corriente parece asimilar la "comunicación estratégica" con aquella comunicación que responde a los nuevos paradigmas. De sus textos se desprende la sensación de que toda comunicación es estratégica siempre que cumpla con esas premisas paradigmáticas de ser compleja, fluida, y significativa. Dentro de esta corriente están algunos de los autores que lideran la reconstrucción del campo:

Sandra Massoni (2005, 2007):

- "Una estrategia de comunicación es en este marco un proyecto de comprensión, un principio de inteligibilidad que busca aborda las múltiples dimensiones de la comunicación como fenómeno complejo -porque incluye múltiples dimensiones- y fluido porque es siempre movimiento, en tanto comunicación es acción".

- "La comunicación estratégica trabaja a partir de un enfoque conceptual y constructivista que utiliza el método comparativo en la recogida de datos y el método de lo contingente en sus interpretación. A través de la comparación etnográfica y discursiva se trabaja en captar la construcción social y lábil de la realidad social para reflexionar y actuar sobre ella. El objetivo es indagar en cada caso la genealogía de los vínculos para dar cuenta de su operar en relaciones concretas".

Marcelo Manucci (2004, 2006, 2008):

- "Considero a la comunicación estratégica como un espacio de sincronía y gestión de significados. La comunicación se transforma en estratégica cuando se posiciona como un proceso que 
permite otorgar un sentido a las percepciones, a los significados $y$ las distintas señales del entorno cotidiano en función de objetivos corporativos compartidos".

- "La comunicación estratégica permite diseñar y gestionar significados".

Daniel Scheinsohn (2009):

- "La comunicación estratégica es una interactividad, una hipótesis de trabajo para asistir a los procesos de significación (...) es una visión compleja de los procesos comunicacionales, radicalmente opuesta a las posturas mecanicistas".

- "La función comunicativa trasciende las fronteras del marketing y debe instalarse en los territorios de la alta dirección".

En estos textos Sandra Massoni pone el énfasis en la comunicación estratégica como lugar de encuentro y de emergencia. Mientras Marcelo Manuccci lo pone en la significación y nos habla de "realidades compartidas" (2004; 2006; 2008). Y si Massoni se remite a la comunicación como un método para hacer emerger nuevos acuerdos relacionales, Manucci (2008) se remite a la comunicación como una herramienta de gestión estratégica necesaria para construir el futuro corporativo (2005) Mientras Scheinsohn pone su énfasis en el paso del nivel táctico al nivel estratégico/directivo.

A3. Llegamos así a un tercer grupo que, aunque muy próximo al anterior en el plano teórico, parece hacer un esfuerzo más directo por caracterizar la comunicación estratégica. Sirva de ejemplo un título muy expresivo: "O que é comunicaçâo estratégica nas organizaçôes" de Ivonne de Lourdes Oliveira y María Aparecida de Paula (2008). Esta corriente -en la que me encuentro- si bien coincide con la anterior en muchas de sus conclusiones cuestiona que sea la significación, la relación o el encuentro lo que permite caracterizar a una comunicación de estratégica. Todos esos rasgos lo que indican es únicamente que dichas comunicaciones responden a los nuevos paradig- 
mas. Lo que realmente hace estratégicas a unas comunicaciones, y no a otras, es que tengan las cualidades que implica el calificativo estratégico. Cualidades que ya hemos comentado (Véase Conclusiones 2.1) pero que vamos a desarrollar a continuación en este nuevo contexto. Esta corriente distingue entre estrategias de comunicación y comunicaciones estratégicas (Alberto Pérez, 2001; Kathy Matilla, 2008; Villegas, 2010).

4. Intercambio y diálogo entre expertos: Llegamos así al cuarto dato que dibuja el actual escenario y es la aparición de redes y plataformas de intercambio entre expertos. La sensación de que se estaba trabajando desde posiciones individualistas o de escuela, y de que era necesario intercambiar hallazgos y posiciones ha propiciado el nacimiento de plataformas de redes de expertos, concebidas como plataformas de intercambio y debate académico. Es el caso del Foro Iberoamericano Sobre Estrategias de Comunicación (FISEC), de GICOM, Grupo hacia una ingeniería de Comunicación Social; de GUCOM, de la Red Académica Iberoamericana de Comunicación (RAIC), y la Sociedad Latina de Comunicación Social (SLCS), por citar redes con presencia en este encuentro.

5. Propuestas de cómo llevar estas convergencias al plano educativo: Los esfuerzos ya emprendidos por trasladar estos avances a la educación (Véase Norma Macías y Diana Cardona en México y Antonio Roveda en Colombia) van ganado apoyos aunque todavía no hayan cristalizado en la práctica. No solo las ideas está claras, también lo están las soluciones y estas son básicamente dos: formar en competencias (la competencia es un saber actuado) y que el perfil del egresado sea el de un estratega de la comunicación capaz de afrontar y resolver los problemas propios del siglo XXI a la manera que lo propone el proyecto Tuning de la Unión Europea y que, a su vez, soporta la Declaración de Bolonia. Algo que no está ocurriendo, pues son muy escasas las Facultades y escuelas de Comunicación y de Periodismo en Iberoamérica que respondan a esas señas. Es momento de llevar estas soluciones a la práctica. 


\section{Conclusiones 2.3}

Ha llegado el momento de intentar responder a las cuestiones que todavía están pendientes. Para ello vamos a agruparlas en dos bloques:

1er. Bloque de cuestiones: ¿son todas las estrategias comunicativas?, ¿'son todas las comunicaciones estratégicas?

Según nuestra investigación la respuesta es NO para ambas cuestiones. No todas las estrategias son comunicativas: ya se ha dicho que se suelen llamar estrategias de comunicación aquellas que persiguen objetivos comunicacionales o tienen en la comunicación su principal componente. Cuando eso no ocurre la estrategia será lo que corresponda: de ventas, financiera, sanitaria, política, militar, etc.

Tampoco todas las comunicaciones son estratégicas. Para que una comunicación sea "estratégica" tiene que cumplir tres requisitos:

1. Tener los rasgos que toda acción estratégica:

- que haya sido concebida para alcanzar una determinada meta o futurible;

- que el sujeto que toma las decisiones se encuentre en una situación de incertidumbre;

- que en su elección el sujeto haya actuado anticipadamente;

- que al hacerlo haya tenido en cuenta las posibles reacciones y decisiones de terceras personas;

- que se hayan evaluado las diversas rutas alternativas que supuestamente conducen al futuro deseado (meta);

- y elegido una, que es la que se ejecuta (Alberto Pérez, 2001).

2. Si además esa acción estratégica es comunicativa debería cumplir también ciertas funciones y tareas propias de su naturaleza comunicacional: Funciones que Riel (1997) concreta en dos; Oliveira y De Paula (2008) en tres y, otros autores (Alberto Pérez, 2001) concretan en cinco (Figura $n^{\circ} 3$ ). Entre las tareas: estar estructurada en función de unas metas descritas o describibles en parámetros comunicacionales (el gap perceptivo que se intenta aminorar, la percepción que se desea obtener, la significación que se desea generar). Que forme parte de una mezcla de sistemas comunicativos previamente definidos (communication mix) y finalmente que se materialice mediante sistemas y acciones comunicativas. 
3. Y si esa acción comunicativa estratégica se mueve dentro de los nuevos paradigmas, entonces tendría que tener otros rasgos adicionales tales como: ser fruto de un pensamiento complejo; no solo hablar/difundir sino también escuchar/dialogar; buscar más la articulación que la persuasión; la conectividad que la difusión; compartir y armonizar nuestras percepciones y valores mas que imponer los nuestros; servir de lugar de encuentro y generación de significación y de sentido compartido y espacio. Pero en este caso no ya por ser estratégica, sino por responder a los nuevos paradigmas.

2do. Bloque de cuestiones: ¿es lo mismo estrategia de comunicación que comunicación estratégica?, ¿estamos ante un interfaz de dos categorías o ante una categoría adjetivada?, ¿ante un tipo de estrategias o ante una subcategoría de la comunicación?

Son escasos los autores que tratan estas cuestiones. Nuestra respuesta es doble (1) estamos ante un interfaz de dos categorías que al unirse se potencian; $\mathrm{y}(2)$ estamos ante un tipo de estrategias y a la vez ante una subcategoría de la comunicación, sencillamente porque estrategias de comunicación y comunicación estratégica son dos cosas distintas aunque muchos autores las utilicen como sinónimos.

Pero lo cierto es que uno de los escasos textos que conozco en que se precisa la diferencia entre ambas categorías lo escribí en 2001 y diez años después sigue expresando mis ideas al respecto. Ruego al lector que me disculpe si me veo obligado a autocitarme. Las razones que entonces esgrimí y que considero que siguen siendo válidas es que la relación entre una comunicación estratégica y una estrategia de comunicación es la de la parte con el todo. Pero no siempre las comunicaciones estratégicas forman parte de una estrategia:

"A las actuaciones estratégicas puntuales (y las comunicaciones estratégicas lo son en muchas ocasiones) les falta la idea rectora que las conecte con las restantes acciones que pudieren producirse en el mismo ámbito y curso de intervención; les falta el esquema director que aporta la estrategia que dé y transmita coherencia, favorezca las sinergias y sobre todo, alumbre el camino a seguir" (Alberto Pérez, 2001).

Concluimos pues que NO todas las comunicaciones son estratégicas y que se pude y se debe diferenciar entre una estrategia de comunicación y una comunicación estratégica. Quisiéramos pensar que la exploración haya servido para acotar el fenómeno y facilitar así la convergencia en torno suyo y propiciar así la unificación del campo.

Mediaciones Sociales, № 10, I semestre 2012, pp. 121-196. ISSN electrónico: 1989-0494. DOI: http://dx.doi.org/10.5209/rev_MESO.2012.n10.39684 


\subsection{Nos queda por explorar el sendero de la vida}

"Una manera útil de estructurar un discurso sobre estrategias es ir a las fuentes. Buscar en las raíces animales los orígenes de nuestras estrategias. Es una idea fecunda la de explorar las líneas de despliegue de las estrategias conductuales de los animales y regresar al comportamiento humano para poner un poco de orden en lo que parece ser una densa selva de posibles variantes estratégicas. Creo que la idea vale la pena".

"No pienso que haya inconveniente de ningún orden para aceptar la hipótesis que nuestras estrategias conductuales tienen un origen animal tal como nos lo explica la psicología evolutiva".

Blas Lara, www.tendencias21.net, 8-12-2009

Se podría pensar que ya hemos terminado nuestra exploración, pero nuestro estado del arte todavía no ha terminado. Nos queda un sendero por explorar. Hay otro espacio académico donde también se habla de estrategia y comunicación pero al que no solemos acudir los comunicadores: las ciencias de la vida.

¿Es la comunicación estratégica un fenómeno biológico? ¿Permitirán las ciencias de la vida integrar toda la riqueza multidisciplinar de la comunicación estratégica en una matriz unitaria de estudio y facilitar la unificación del campo? ¿Es la evolución en sí una estrategia para la supervivencia de la propia vida? Esas son precisamente las cuestiones que estamos investigando en otro espacio: el "Proyecto de Investigación Estrategar" de FISEC 5 :

- Estrategar, una línea abierta de investigación: Propuesto en la universidad Iberoamericano de México D.F. (Alberto Pérez, 2005b) con motivo del V encuentro Iberoamericano de FISEC, "Estrategar" es un proyecto de Investigación que tengo el honor de coordinar. Se puso en marcha en Julio 2010 con el apoyo de la revista científica on line www.tendencias21.net y

5 Ya comenté antes que FISEC encontró dos puntos débiles a las actuales formulaciones en Estrategia, uno es su debilidad teórica y la respuesta de FISEC fue la NTE. El segundo punto débil es el proceso estratégico. Una debilidad que ya habían reconocido Minzberg y sus colegas en Strategy Safary (1998) pero que sigue siendo una cuestión pendiente. Pues bien la respuesta de FISEC ha sido el Proyecto de Investigación Estrategar.

Mediaciones Sociales, № 10, I semestre 2012, pp. 121-196. ISSN electrónico: 1989-0494.

DOI: http://dx.doi.org/10.5209/rev_MESO.2012.n10.39684 
de su Director Eduardo Martínez de la Fe. Trabajan en él de forma transdisciplinar 62 expertos y docentes de 18 disciplinas científicas distintas. Su objetivo es dar una explicación de cómo los seres humanos concebimos y procesamos nuestras estrategias. Una explicación que todavía no dispone la ciencia actual. Su planeamiento y el grado tan alto de multidisciplinariedad hacen que "Estrategar" sea una de esas líneas de investigación que indican por donde podrían ir los trabajos futuros.

- Planteamiento: Toda investigación se hace desde una perspectiva. "Estrategar" asume la biología sistémica de Maturana y Varela. Como es bien sabido, en 1968 Maturana decidió plantearse el problema del conocimiento, no desde la perspectiva del sistema nervioso sino desde la perspectiva del operar biológico completo del ser vivo. "Decidí considerar qué procesos deberían tener lugar en el organismo durante la cognición, considerando así la cognición como un enfoque biológico" (1969). El resultado fue una nueva visión sobre los seres vivos y sobre la naturaleza cognoscitiva del ser humano, que ha dado lugar a una trama teórica unificada de las ciencias de la vida y las ciencias sociales, e incluso a un replanteamiento de la naturaleza de la condición humana (Behncke,1984). Ese enfoque les permitió a Maturana y Varela decir que "vivir es conocer" (El árbol del conocimiento, 1984). Y nosotros ahora nos planteamos $\dot{\mathrm{C} V i v i r}$ es estrategar?

-Conceptualización: La primera tarea fue consensuar desde las 18 disciplinas de "Estregar" un concepto de Estrategia válido para todas ellas. Nos llevó cerca de un año: "La estrategia es un sistema de vigilancia y armonización con el entorno, orientado inicialmente a dar respuestas orientadas la gestión de la supervivencia".

- Explorando el sendero de la vida: La investigación consta de tres exploraciones: la $1^{\mathrm{a}}$ para saber si existen o no respuestas elaboradas para esta cuestión desde la Comunicación. La $2^{\text {a }}$ desde la Estrategia y la $3^{\text {a }}$ desde las Ciencias de la Vida.

- Desde la Comunicación: Con la excepción de Manuel Martín Serrano la literatura sobre Comunicación no suele abordar la problemática comunicativa desde la vida, sino en todo caso desde lo social, pero se pueden encontrar algunas aportaciones interesantes aisladas sobre:

a) La comunicación como mecanismo evolutivo.

b) Las estrategias de coordinación del grupo. 
c) El papel de lo simbólico.

d) La construcción lingüística de la realidad.

- Desde la Estrategia: La literatura sobre Estrategia tampoco suele abordar la problemática estratégica desde la vida, sino desde lo militar, la economía o el management. Encontramos algunas aplicaciones sistémicas, eco-sistémicas y evolucionistas. Entre ellas, el clásico de Lawrence y Lorsch "La empresa y su entorno" (1967); las aportaciones ecosistémicas de Brown y Diguid (1991) sobre gestión de la sostenibilidad y las de Laszlo y Laugel, en su L'Economie du Chaos, (1998) sobre co-evolución.

- Desde las Ciencias de la Vida: En cambio si encontramos una interesante literatura sobre la Estrategia y la Comunicación desde las ciencias de la vida. Aunque nunca como objeto central: falta una historia evolutiva de la estrategia. Y eso es precisamente lo que "Estrategar" aspira a cumplir.

- 7 avances sobre los resultados provisionales: Aunque tardaremos tres años en terminar la investigación se pueden anticipar algunos avances parciales que nos deberían permitir hacernos una idea de a dónde nos podría llevar esta línea de investigación ${ }^{6}$.

(1) La vida implica indeterminación: Hoy prospera la tesis de que el Universo tiene una estructura profunda matemática explicable a partir de una billonésima de segundo después del Bing Bang (hace 15.000 millones de años) mediante unos pocos números y leyes matemáticas, que algunos autores (Rowan-Robinson, 2002) reducen a 9 y otros a menos. Pero en un mundo en el que todo lo demás está determinado, con la vida aparece "una zona de indeterminación". Esta noción de "margen o banda de indeterminación" es clave pues permite ubicar la estrategia en una historia vital "no escrita del todo". Y no dentro de

6 Estrategar ha celebrado ya dos reuniones anuales, la última el pasado mes de julio en la Casa de América de Madrid, pero queda un largo camino por recorrer. No esperamos tener resultados finales hasta 2014/2015. Tampoco hemos decidido cómo difundir los resultados parciales. Por ello hoy aquí me voy a limitar a comentar muy brevemente la literatura que puedo manejar: mis propios textos al respecto y los de 4 otros investigadores de Estrategar ya publicados fuera del proyecto. Con su permiso no voy a hacer un recorrido tan detallado como los anteriores, me voy a limitar a explicar en qué consiste esta línea de investigación.

Mediaciones Sociales, № 10, I semestre 2012, pp. 121-196. ISSN electrónico: 1989-0494.

DOI: http://dx.doi.org/10.5209/rev_MESO.2012.n10.39684 
una trama de determinismo genético: "Lo que hay es un fenómeno de epigénesis: (...) el organismo va surgiendo en una historia (...) Las condiciones genéticas constituyen la estructura inicial del organismo, el fundamento para el desarrollo, pero no determina el curso de la epigénesis porque este va surgiendo como un fenómeno histórico" (Maturana, 1997). Allí donde las interacciones entre las aplicaciones del programa genético y los condicionantes del medio ambiente exigen nuevas repuestas, se abre para los seres vivos un margen de maniobra. Lo llamamos adaptación. La vida no es mera ejecución del programa sino que implica creación (Bergson); ruido/caos (Von Foester); autopoiésis (Maturana y Varela) y decisión (Morin). Pero esa "zona de indeterminación" no es la misma para todos los seres vivos: aumenta en la medida en que se avanza en la filogénesis.

(2) La vida es relación: La vida implica relación con el medio ambiente y a esa relación se la llama comunicación: se habla así de comunicación celular como la capacidad que tienen todas las células de intercambiar información fisicoquímica con el medio ambiente y con otras células. Los organismos no "se adaptan" mecánicamente a un medio fijado de antemano, a un "nicho" exterior autónomo, sino que -en cierta medida- "lo construyen" a través de sus propias actividades vitales. En consecuencia, tanto los organismos como su ecosistema se encuentran en un estado de constante flujo, de fluidez, en donde se modifican y reconstruyen continuamente al interactuar entre sí, "acoplándose" de forma mutua y recíproca (Lewontin, 2000; Moriello, 2005).

(3) Las estrategias son respuestas (orientadas al equilibrio y a la supervivencia): Todo ser vivo para seguir siéndolo tiene que cumplir unas funciones vitales (que le permitan sobrevivir, reproducirse y autoproducirse). Esas funciones se cumplen gracias a determinados procesos operacionales que les permiten percibir y detectar discontinuidades en su entorno (vigilia); identificar mediante marcadores somáticos si esas discontinuidades afectan a su supervivencia (umbral de riesgo); y elaborar sus respuestas. A esas respuestas se les llama estrategias.

Las estrategias son para las ciencias de la vida las respuestas homeostáticas de los seres vivos a las variaciones del medio externo. Si lo comparamos con el significado que ya hemos comentado en 2.1: “...se 
entenderá por estrategias el conjunto de elecciones que se adoptan para alcanzar determinadas metas o resolver determinados problemas teniendo en cuenta la intervención, real o potencial, de otras fuerzas, seres o sistemas". Vemos que todo encaja menos, tal vez, la palabra "elecciones", que requiere la capacidad de evaluar entre alternativas, algo que emerge en el curso de la evolución.

Vemos así como conceptos antes reservados para los humanos se están ampliando a todos los seres vivos. Es el caso de la relación/comunicación y de la respuesta/estrategia. También es el caso de la inteligencia, que comienza a ser aplicada (y no como una metáfora) a todos los organismos vivos.

"Las plantas no tienen cerebro, las plantas no tienen ni una sola neurona...pero ahora sabemos que las plantas perciben lo que sucede a su alrededor, se defienden contra sus depredadores, engañan a sus presas, e incluso se comunican entre ellas (...) Si se define inteligencia como la capacidad de resolver problemas, las plantas tienen mucho que enseñarnos" (Stefano Mancuso, botánico, Universidad de Florencia. Emisión 16 de enero 2011 del Programa Redes de TVE: Las raíces de la inteligencia de las plantas).

(4) Hay varios tipos de estrategias: Los organismos vivos pueden reaccionar a los cambios de su medio de dos formas o de ambas: (a) Mediante respuestas homeostáticas a desequilibrios inducidos desde el medio externo; y (b) con reajustes internos que implican cambios estructurales adaptativos:

- Respuestas externas:

- Comportamiento innato: Son respuestas genéticamente heredadas. Ejemplos: la creación de nidos por parte de las aves, el vuelo de una mariposa recién nacida, el tejido de la tela de araña.

- Comportamiento aprendido: Todas las operaciones de respuesta van a quedar "grabadas" en la memoria y dejarán "huellas" que abrirán vías de preferencia para las nuevas respuestas a situaciones similares. Ejemplos: aves que aprenden a no comer aquellos insectos de sabor desagradable; el tigre que en el circo pasa por 
un aro de fuego. Ese aprendizaje puede ser el resultado de una experiencia individual o inducido culturalmente.

\section{- Reajustes internos:}

- Comportamiento adaptativo: Son los cambios estructurales internos, las reacciones morfológicas que desarrollan los organismos para poder vivir bajo determinadas condiciones (cambiantes) del ambiente. Ej. las espinas del cactus para retener agua. Estos comportamientos no son excluyentes. En base a su morfología cada especie establece la combinación de innatismos y conductas aprendidas que le va a permitir un repertorio particular de respuestas. Lo importante para nosotros es que a estas respuestas conductuales características se les llama estrategias. Y han sido objeto de diferentes intentos de clasificación:

- Por su forma de adaptarse al medio: "K" $\mathrm{y}$ "r"

Los expertos hablan de 2 estrategias adaptativas básicas: la "K" y la "r". A partir de los estudios de biogeografía de islas realizados por los ecólogos Robert MacArthur y E. O. Wilson (1967) los biólogos hablan de selección $\mathrm{r} / \mathrm{K}$ para referirse a los dos tipos básicos de selección natural (tamaño poblacional, reproducción, cuidado de e las crías, etc.).

- Por su finalidad: 7 estrategias tipo:

- Estrategias de caza/alimentación.

- Estrategias de cortejo/sexo/pareja.

- Estrategias de juego/simulación/aprendizaje.

- Estrategias de comunicación.

- Estrategias de socialización/coordinación del grupo.

- Estrategias de camuflaje y huida.

- Estrategias de sanación.

- Por la manera de relacionarse con los otros organismos: 4 estrategias básicas:

- Depredación: el beneficio del uno es a costa del otro. 
- Necrosis: nadie se beneficia solo se hace daño.

- Parasitismo: una parte de aprovecha de las otra.

- Simbiosis: ambas se benefician. Es la única que es cooperativa y

"crea" beneficios.

"La agresión no es ventajosa para la evolución: aplicada a la biología, la teoría de los juegos desvela que la cooperación es preferible a la confrontación. En el mundo microscópico, una agresión intensiva no es eficaz a largo plazo, según Martin Nowak y Karl Sigmund de la Universidad de Harvard y del Instituto de Matemáticas de la Universidad de Viena, respectivamente, que tal como explican en la revista Science han aplicado la teoría de los juegos al ámbito de la biología. (...) La teoría de los juegos, que constituye un desarrollo de la teoría de los juegos de azar aplicada hasta ahora a la economía y la estrategia militar, puede aplicarse también a la biología y obtener de ella grandes enseñanzas" (Eduardo Martínez, www.tendencias21.net).

(5) La adopción de un tipo u otro de estrategia se rige en cada especie por ciertas leyes o principios: (Rafael Alberto Pérez, 2001):

- La ley de la "especialización de las especies" (valga el juego de palabras). Plantas, flores, papagayos, mariposas, peces tropicales han aplicado con éxito la diferenciación biológica y de imagen. Una idea que encontramos en Adam Smith y en 1 de las 3 estrategias de Porter (1980, 1985).

- La ley del balance energético favorable: Los organismos que dispongan de un balance más favorable que el de los que conviven con él en un mismo hábitat tienen una mayor oportunidad de supervivencia (Byrne y Whiten, 1988; Hass, 1970). Una idea que Cuno Pümpin y García Echevarría (1986) trasladarían al mundo empresarial.

- El principio de optimización: En ecología del comportamiento y en biología evolutiva se suele hablar de optimización para referirse a aquellas estrategias que ofrecen el mejor retorno a un animal teniendo en cuenta todos los diversos factores y apremios que intervienen en una situación dada. Se llega a una solución óptima considerando las ventajas y los costes de un comportamiento. $\mathrm{Si}$ los costes superan a las ventajas entonces ese comportamiento no 
se desarrollará y viceversa. Un ejemplo nos lo dan los lagartos. La cantidad de tiempo que ocupan en comer está condicionado por la necesidad de tomar el sol para regular su temperatura corporal (constreñimiento intrínseco): cuanto más mejor y la presión de no exponerse a que lo descubran los posibles depredadores (constreñimiento extrínseco de riesgo): cuanto menos mejor.

- La Ley de la suma positiva: La teoría de los juegos demuestra que cuando las interacciones son de suma positiva esta es la mejor opción. Este sería el caso de las estrategias cooperativas pues favorecen la supervivencia. Una idea que asume la Nueva Teoría Estratégica de FISEC (2001). Otra aplicación son las llamadas Estrategias Evolutivamente Estables (ESS) propuestas por John Maynard Smith y George R. Price 1973 (Evolution and the Theory of Games, Maynard Smith, 1982) para señalar que la selección natural evita que los jugadores utilicen otras estrategias alternativas que lleven a recompensas menores de las actuales.

(6) A lo largo de lo filogénesis los procesos operacionales de respuesta estratégica se han ido modificando: Venimos asistiendo a un largo proceso en el que a medida que subimos en la escala evolutiva y los organismos crecen en complejidad las respuestas innatas iniciales van dejando más espacio a otras más sofisticadas en las que intervienen sistemas de evaluación como las emociones y cierto tipo de cálculos más complejos (distancias, fuerzas). Y esto es así porque el comportamiento adaptativo al producir cambios morfológicos posibilita la aparición de nuevas capacidades. A su vez la emergencia de estas nuevas capacidades da lugar a nuevos procesos operacionales capaces de modificar y hacer más poderoso los sistemas estratégico y comunicativo en su conjunto.

La biodiversidad nos enseña que una misma función (v. gr. la reproducción) puede ser satisfecha mediante sistemas operacionales muy alejados los unos de los otros. Y la evolución nos sitúa en un proceso dinámico en el que a medida que surgen nuevas capacidades los procesos operacionales cambian y las respuestas se vuelven más sofisticadas. Como explica con acierto Blas Lara (2009) la especiación significa a lo largo del tiempo variaciones morfológicas. Pero también la aparición de nuevas estrategias adaptativas para capturar una presa, 
para escapar a un depredador, para reproducirse. La psicología comparativa actual nos muestra cómo la adaptación a los diferentes nichos ecológicos ha ocasionado el despliegue de las diferentes habilidades cognitivas y refinamientos estratégicos, como la huida, la ficción, el cálculo, etc. que van más allá del simple esquema behaviorista estímulo / respuesta. Y que suponen adaptaciones a lo largo del tiempo del sistema de control del organismo vivo. Me refiero especialmente al cerebro. Durante la evolución la fisiología animal va adquiriendo funciones nuevas al mismo tiempo que nuevas estructuras cerebrales se constituyen. Funciones y cerebro interactúan en bucle. (Blas Lara, 2009).

(7) El sistema estratégico humano: ruptura o emergencia: Aquí hay que tener en cuenta un hecho evolutivo y es que las nuevas capacidades se añaden a las anteriores. No las eliminan, aunque se puedan llegar a atrofiar por falta de su uso. Y por eso todo ser vivo lleva dentro de sí la evolución completa que le ha precedido. Algo que en los seres humanos se evidencia en los embarazos, donde se observa como la ontogénesis reproduce a la filogénesis. El embrión humano de un mes de edad posee una serie de fosas branquiales pareadas en la región del cuello que recuerdan a las de los peces. La posesión temporal de una cola y la existencia de un corazón de dos cámaras son también ejemplos de estadios de desarrollo por los cuales atraviesa el embrión humano. Y eso explica también el que nuestro cerebro sea triuno (Paul MacLean, 1990) formado por un cerebro reptiliano, otro límbico o paleomamífero y el cerebro neomamífero, propio de los mamíferos evolucionados o superiores y ubicado en el neocortex, es el cerebro humano más evolucionado. Sperry, Gazzaniga y Bogen los consideraron en dos hemisferios (izquierdo y derecho) con funciones específicas.

Todo indica que esos primeros humanos heredaron el sistema estratégico de sus antecesores y que a partir de la presión medioambiental lo fueron modificando primero adaptativa y después culturalmente. En momentos dados de la evolución de homo fueron apareciendo ciertas capacidades emergentes: simbólica, hermenéutica, imaginativa, prospectiva, comunicativa, de cálculo etc. que se acoplaron en un sistema operativo estructuralmente articulado capaz de adoptar ante las 
presiones del vivir determinados cursos de acción que hoy llamamos estrategias humanas.

Ernst Cassirer nos bautizó de homo simbolicus.

Fue de esta forma como el sistema estratégico se amplió:

- De decidir a elegir.

- De presente a futuro.

- De vigilar a anticipar intenciones.

En todos esos cambios tuvo que ver la comunicación.

1) De decidir a elegir: Los animales deciden qué hacer. Los seres humanos elegimos entre alternativas. Es la proairesis de los griegos. Y elegimos porque cada uno vemos cosas distintas (cosas distintas que tienen consecuencias distintas). $\mathrm{Y}$ vemos cosas distintas porque interpretamos una realidad para nosotros polisémica. Los animales descodifican una realidad para ellos monosémica.

"Señales y símbolos -nos advierte Charles Morris- corresponden a dos universos diferentes del discurso: una señal es una parte del mundo físico del ser; un símbolo es una parte del mundo humano del sentido. Las señales son 'operadores'; los símbolos son 'designadores'”.

Y al elegir nos bifurcamos: Fue Lawrence Durrell quien llamó al ser humano "Esa pobre criatura bifurcada" y Jorge Luis Borges quien nos habló del "El jardín de los senderos que se bifurcan".

Nuestras estrategias nacen en nuestras distintas interpretaciones de la realidad. Surge ahí en el origen una conexión profunda entre estrategia y comunicación. La polisemia (un rasgo semántico) está en el origen de las estrategias humanas.

Los olores, colores y sonidos del mundo son para losa animales señales -signos con un único significado, es decir monosémicos- que les aportan pistas para su supervivencia. Así, el "crick" de una hierba seca al romperse en la sabana es una señal que avisa de la posible presencia oculta de un león. Se descodifica como: peligro. La vida está en juego y no caben interpretaciones. Pero no solo perciben una realidad monosémica también se comunican entre sí mediante señales sonoras y

Mediaciones Sociales, № 10, I semestre 2012, pp. 121-196. ISSN electrónico: 1989-0494.

DOI: http://dx.doi.org/10.5209/rev_MESO.2012.n10.39684 
gestuales monosémicas. Al oír ese "crick-peligro" la gacela líder reacciona avisando al resto de la manada mediante un sonido que figura en su repertorio para esas situaciones y todas las gacelas salen huyendo al unísono. Hoy conocemos ya los repertorios de señales de algunas especies, suelen ser cortos y orientadas, al igual que sus estrategias, a la supervivencia y a la adaptación. Lo que están permitiendo su "traducción" por los expertos. En concreto "Un fabricante japonés ha desarrollado un traductor para el lenguaje gatuno (...) el nuevo aparato tiene el tamaño de una caja de cigarrillos y se llama "Meowlingua". La misma empresa lanzó este año un aparato para traducir al japonés e inglés los ladridos de los perros. (de la prensa)

2) De vigilar el presente a anticipar el futuro: Mal podríamos elegir si no tuviésemos la capacidad de imaginarnos las consecuencias futuras de nuestros actos. Pero no solo nos anticipamos al futuro también nos anticipamos las intenciones de los demás. La evolución ha especializado algunas neuronas (espejo) para que podamos inferir las intenciones ajenas (teoría de la mente). Las estrategias humanas son nuestra reacción presente al futuro.

Todas las lenguas tienen un tiempo de futuro que nos permite viajar en el tiempo e imaginarnos el nuestro (futuribles). Y hoy sabemos que la comunicación no solo sirve para la coordinación del grupo (hace comunidad) sino también para la predicción y el control de los otros (reducción de la incertidumbre).

3) De cerrado a abierto: Quedaba una cuestión por resolver ¿Cuál es la ventaja evolutiva de la polisemia? La monosemia es más fiable. Solo hay un pequeño problema: un perro vive una vida de perro y un gato....; no salen de la circularidad de su mundo animal.

En cambio la ventaja es que de la polisemia, de la connotación, del "cerebral noise" emergen nuevas opciones: el hombre crea nuevas conexiones y abre nuevas rutas. Juan vive la vida de Juan, Pedro la de Pedro, Vd. la suya y yo la mía. Al bifurcamos creamos nuestra identidad como individuos. La innovación es pues la gran ventaja evolutiva de la polisemia. El ser humano es el único ser vivo que se ha salido del guión y se "monta sus propias películas". 


\subsection{Conclusiones finales}

Hemos recorrido cuatro senderos. Y hemos visto los desplazamientos de la comunicación y la estrategia hacia los nuevos paradigmas científicos.

También hemos apreciado una tendencia a su encarnación en seres humanos y en sujetos colectivos (organizaciones).

Nos falta dar el salto: encarnar el fenómeno de la comunicación estratégica en la trama de la Vida. mica.

Darle así su dimensión biológica y no solo social, política o econó-

Cuando la hayamos hecho podremos ver como estrategia y comunicación se potencian mutuamente y podremos explicar las bases funcionales de esas operaciones.

Me gustaría pensar que cuando demos ese paso y hayamos insertado estrategia y comunicación en la trama de la vida, la tarea de la unificación del campo de estudio será más evidente y vendrá de sí.

Que así sea. ¡iMuchas Gracias!! 


\section{BIBLIOGRAFÍA}

AlBerto PÉREZ, R. (2001): Estrategias de comunicación. Barcelona: Ariel.

Alberto PÉREZ, R. (2003a): "Por que é necessária uma nova teoria estratégica?", Marketeer, $\mathrm{n}^{\circ} 85$.

Alberto PÉRez, R. (2003b): "La nueva teoría estratégica pasa por Santiago", Boletín Chileno de Comunicación, $\mathrm{n}^{\circ} 54$.

Alberto PÉREZ, R. (2004a): "El siglo XXI exige una manera distinta de pensar los conflictos y sus estrategias”, Tendencias 21, 9/08/2004. Disponible en www.tendencias21.net. Consultado el 20 de septiembre de 2007.

Alberto PÉREZ, R. (2004b): "Podemos hacer mejor las cosas: Hacia una nueva teoría estratégica refundada desde la comunicación”, Interacción, n ${ }^{\circ}$ 36-40. Disponible en http://www.cedal.org.co/index.shtml? s=h\&m=a. Consultado el 15 de julio de 2005 .

Alberto PÉREZ, R. (2005a): "La nueva teoría estratégica: Estado de la cuestión”, Fisec-estrategias, año I, $\mathrm{n}^{\circ}$ 1. Disponible en http://www.fisec-estrategias.com.ar/

Alberto PÉREz, R. (2005b): "Estrategar: el fenómeno perdido de la teoría estratégica”, Fisec-estrategias, año I, $\mathrm{n}^{\circ} \quad 2$. Disponible en http://www.fisecestrategias.com.ar/

AlBerto PÉREZ, R. (2006): "Estrategias de comunicación para las revistas científicas”, en VV.AA.: Diálogos entre Editores Científicos Iberoamericanos. Buenos Aires: CAICYT - CONICET.

AlBerto PÉREZ, R. (2006): "Razones para una nueva teoría estratégica", www.comminit.com y Encontros Científicos, $\mathrm{n}^{\circ} 2$.

Alberto PÉREZ, R. (2007a): "Las 7 señas de identidad de la nueva teoría estratégica”, Fisec-estrategias, año III, no ${ }^{\circ}$. Disponible en http://www.fisecestrategias.com.ar/

Alberto PÉREZ, R. (2007b): "Nuevos paradigmas en comunicación estratégica”, Tendencias 21, 22 marzo, 30 marzo, 15 mayo y 25 junio de 2007. Serie de cuatro artículos. Disponibles en: www.tendencias21.net 
Alberto PÉREZ, R. (2008): "Siete cambios que conducen a una nueva teoría estratégica más humanizada”, en VV.AA.: Comunicación, ciudadanía y valores. Reinventando conceptos y estrategias. Quito: Organización Católica Latinoamericana y Caribeña de Comunicación (OCLACC) / Universidad Técnica Particular de Loja (UTPL).

Alberto PÉREZ, R. (2008): Estrategias de Comunicación. Barcelona: Ariel ( $\left.4^{\mathrm{a}} \mathrm{ed}\right)$.

Alberto PÉRez, R. (2010): "Pensar la acción”. Prólogo a Múnera Uribe, P. A.: La articulación teoría-práctica en la comunicación. Barranquilla: Universidad Autónoma del Caribe.

Alberto PÉrez, R. y Martínez Ramos, E.: (1981): La estrategia de la comunicación publicitaria. Madrid: Instituto Nacional de Publicidad.

Alberto PÉREz, R y MAssoni, S. (2009): Hacia una teoría general de la estrategia. El cambio de paradigma en el comportamiento humano, la sociedad y las instituciones. Barcelona: Ariel.

Alberto PÉRez, R. y Suso, J. (1977): La eficacia de la Publicidad ante las actitudes del consumidor. Madrid: Instituto Nacional de Publicidad.

ALDRICH, H. y HERKER, D. (1977): "Boundary spanning roles and organisational structure”, Academy of Management Review, 2, 217-30.

Alonso Baquer, M. (2000): ¿En qué consiste la estrategia? Madrid: Ministerio de Defensa.

AnsofF, I. (1976): From strategic planning to strategic management. New York: John Wiley.

AnsofF, I. (1979): Strategic Management. Londres: Mc Millan.

ARANGUREN, J. L. (1975): La comunicación humana. Madrid: Guadarrama.

Arceo Vacas, A. (1999): Estrategias de Relaciones Públicas. Metodologías. Madrid: ICIE.

Argenti, J. (1996): "Corporate Communication as a Discipline: Toward A Definition”, Management Communication Quarterly, 10 (1), pp. 73-97.

Argenti, P., Howell, P. y Beck, K. (2005): "The Strategic Communication Imperative", MIT Sloan Management Review, 46(3), pp. 83-89. 
AUdy (1973): Estrategia publicitaria y de Marketing. Madrid: Guadiana.

Ávila, R. (2004): Crítica de la comunicación organizacional. México: UNAM.

Bartoli, A. (1991): Communication et organisation. Pour une politique general cohérente. Paris: Editions d'Organisation.

BELtrán SAlmón, L. R. (2000): Investigación sobre comunicación en Latinoamérica. Inicio, trascendencia y proyección. La Paz: Plural / Universidad Católica Boliviana.

Berger, P. L. (ed.) (1999): Informe Bertelsmann: Los límites de la cohesión social. Conflictos y mediación en las sociedades pluralistas. Barcelona: Galaxia Gutenberg.

Berger, Ch. y CALABRese, R. (1975): "Towards a developmental theory of interpersonal communication”, Human Communication Research, I.

BERnAYS, E. L. (1955): The Engineering of Consent. Norman, OK: The University of Oklahoma Press.

Bettinghaus, E. (1966): Message preparation: the nature of proof. Indianapolis.

BogarT, L. (1967): Strategy in Advertising. New York: Harcout, Brace \& World.

Borden, G. A. (1974): Introducción a la teoría de la comunicación humana. Madrid: Editora Nacional.

Borden, N. H. y Marshall, M. V. (1959): Advertising management.

Botan, C. H. y Hazleton, V. JR. (1989): Public Relations Theory. New Jersey: Lawrence Erlbaum Ass.

BoyRI, Ph. A. (1989): Les relations publiques ou la strategie de la confiance. París: Eyrolles.

Braidot, N. P. (2005): Neuromarketing. Neuroeconomía y negocios. Madrid: Puerto Norte-Sur.

Brown, J. S. y DuguiT, P. (2001): "Organizational learning and communities of practice: towards a unified view of working learning and innovation”, Organization Science, vol. $2, \mathrm{n}^{\circ} 1$, pp. 40-57.

Buchanan, J. y Tullock, G. (1980): El cálculo del consenso. Madrid: Espasa Calpe. 
Bueno, W. (2003): Comunicaçâo empresaitial: teoría e pesquisa. Barueri: Manole.

BYRnE, R. y Whiten, A. (eds.) (1988): Machiavellian Intelligence: social expertise and the evolution of intellect in monkeys, apes and humans. New York: Oxford University Press.

Canella, R., Tsuji, T., Albarello, F. (2005): "Procesos digitales como Estrategias de de Comunicación para la Reducción de la Brecha”, Razón y Palabra, juniojulio de 2005.

CAPRiotti, P. (1999): Planificación estratégica de la imagen corporativa. Barcelona: Ariel.

CARDoso, C. (ed.) (2002): Comunicaçâo organizacional hoje. Lauro de Freitas: Unibahía Editora.

CARnAP, R. (1942): Introduction to Semantics. Cambridge: Harvard University Press.

Castro Nogueira, L., Castro Nogueira, L. A. y Castro Nogueira, M. Á. (2008): ¿Quién teme a la naturaleza humana? Madrid: Tecnos.

Caywood, C. L. (ed.) (1997): The Handbook of Strategic Public Relations \& Integrated Communications. New York: McGraw-Hill.

CIESPAL (1973): "Seminario sobre la investigación de la comunicación en América Latina”, Informe Provisional, Chasqui, primera época, $\mathrm{n}^{\circ} 4$.

Conrad, C., Poole, M. S. (1994): Strategic Organizational Communication. Fort Worth: Harcourt Brace.

Cushman, D. P. (1977): "The rules perspective as a theoretical basis for the study of human communication”, Communication Quartely, $\mathrm{n}^{\circ} 25$.

Cutlip, S. M. y Center, A. H. (1952): Effective public relations. Pathways to public favour. Englewood Cliffs: Prentice Hall.

Cutlip, S., Center, A. y Broom, G. (1994): Effective Public Relations. Englewood Cliffs, NJ: Prentice Hall (7th edn).

Damasio, A. R. (1994): Descartes's error. New York: G.P. Putnam’s Sons. Edición en castellano (1996): El error de Descartes. Barcelona: Drakontos Crítica.

Mediaciones Sociales, № 10, I semestre 2012, pp. 121-196. ISSN electrónico: 1989-0494.

DOI: http://dx.doi.org/10.5209/rev_MESO.2012.n10.39684 
DE KerCKhoven, D. (1999): La piel de la cultura. Barcelona: Gedisa.

De Salas Nestares, M. I. (2005): "Pienso luego Participo, clave de las estrategias para la gestión del conocimiento en la red”, Fisec-estrategias, año I, n 2 . Disponible en http://www.fisec-estrategias.com.ar/

De Wit, B. y Meyer, R. (1998): Strategy, Content, Context. New York: West Publishing Company.

DitchteR, E. (1960): The Strategy of Desire. Nueva York.

DOLPHIN, R. R. y FAN, Y. (2000): "Is corporate communication a strategic function?”, Management Decision, 38 (1/2).

Drucker, P. F. (1954): The Practice of Management. Harper \& Row.

DruCKER, P. F. (1993) (1973): Management: Tasks, Responsabilities, Practices. New York: Harper \& Row.

DURRELL, L. (1957): Justine. Edición en castellano (1987): El cuarteto de Alejandría. Barcelona: Edhasa.

ECHeverría, R. (1994): Ontología del lenguaje. Santiago de Chile: Dolmen.

Edelman, M. (1988): Constructing the Political Spectacle. University of Chicago Press.

FAuconier, G. (1975): Mass media and Society. Lovaina: Leuven University Press.

FERRARI, H. R. (2007): “Un abordaje etológico para el estrategar en humanos”, en VV.AA.: Comunicación estratégica: experiencias, planificación e investigación en marcha. Argentina: Universidad Nacional de Rosario.

Fisher, R y URY, W. (1983): Getting to yes: Negotiating Agreement Without Giving In. New York: Penguin Books.

FOLlaRI, R. (2000): “Comunicología latinoamericana: Disciplina a la búsqueda de un objeto”, PCLA (Pensamiento Comunicacional Latinoamericano), vol. $2, \mathrm{n}^{\circ} 1$. Disponible en http://www.metodista.br/unesco/PCLA/revista5/forum\%205-3.htm. Consultado el 5 de septiembre de 2002.

FreIre, P. (1970): Pedagogía del oprimido. México: Siglo XXI.

Mediaciones Sociales, № 10, I semestre 2012, pp. 121-196. ISSN electrónico: 1989-0494.

DOI: http://dx.doi.org/10.5209/rev_MESO.2012.n10.39684 
FREITAS, R.; LuCAS, L. (eds.) (2002): Desafíos contemporâneos em comunicaçâo: perspectivas de relaçâos públicas. Sao Paulo: Summus.

Fuentes Navarro, R. (1992): Un campo cargado de futuro. El estudio de la comunicación en América Latina. México: CONEICC.

Fuentes Navarro, R. y SÁnchez Ruiz, E. E. (1989): Algunas condiciones para la investigación científica de la comunicación en México. Guadalajara: ITESO (Cuadernos Huella, $\left.\mathrm{n}^{\circ} 17\right)$.

Fuentes Navarro, R. y SÁnchez Ruiz, E. E. (1992): "Investigación sobre comunicación en México: Los retos de la institucionalización”, en OROzCO, G. (coord.): La investigación de la comunicación en México: Tendencias y perspectivas para los noventas. México: Universidad Iberoamericana (Cuadernos de Comunicación y Prácticas Sociales, nº 3 ).

Galindo, J. y LunA, C. (coords.) (1995): Campo académico de la comunicación: Hacia una reconstrucción reflexiva. Guadalajara: ITESO / Consejo Nacional para la Cultura y las Artes.

GAlindo CÁCERES, J. (2005): Hacia una comunicología posible. Universidad Autónoma de San Luis de Potosí.

GAlindo CÁcEREs, J. (2011): "Comunicación Estratégica e ingeniería social en comunicación”, Razón y Palabra, nº 75 .

Glenn, J. C., Gordon, T. J. y Florescu, E. (2010): 2010 State of the Future. The Millennium Project.

Goleman, D. (1995): Emotional Inteligencie. Edición en castellano (1996): Inteligencia emocional. Barcelona: Kairós.

Gruning, J. E., y HunT, T. (1984): Managing Public Relations. Forth Worth: Harcourt Brace.

GRUNIG, J. E. y REPPER, F. C. (1992): “Strategic management, publics and issues”, en Grunig, J. E. (ed.): Excellence in Public Relations and Communications Management. Hillsdale, NJ: Lawrence Erlbaum Associates.

Gumucio Dagrón, A. (2001): Haciendo Olas: Historias de Comunicación Participativa para el Cambio Social. New York: Fundación Rockefeller.

Mediaciones Sociales, № 10, I semestre 2012, pp. 121-196. ISSN electrónico: 1989-0494.

DOI: http://dx.doi.org/10.5209/rev_MESO.2012.n10.39684 
GuMUCiO DAGRón, A. (2009): "Modelo estratégico de comunicación para el cambio social y el desarrollo", en AlBERTO PÉREZ, R y MASSONI, S.: Hacia una teoría general de la estrategia. El cambio de paradigma en el comportamiento humano, la sociedad y las instituciones. Barcelona: Ariel.

Habermas, J. (1973): The Theory of Comunicative Action. Volumen II: Lifeworld and System: A Critique of Functionalist Reasoning. Boston: Beacon Press. Edición en castellano (1987): Teoría de la acción comunicativa. Racionalidad de la acción y racionalidad social. Taurus: Madrid.

HAMEL, G. (2008): The Future of Management.

Hamel, G. (2009): “Moon Shots for Management”, Harvard Business Review, February 2009.

HASs, H. (1970): Energon: Das verborgene Geheimnis (Energon: The hidden secret).

Hax, A. (1990): "Redefining the Concept of Strategy and the Strategy Formation Process”, Planning Review, 18(3), pp. 34-40.

Hopkins, C. (1923): Scientific Advertising. New York: Lord \& Thomas.

IBÁÑEZ, J. A. (1990): "Nuevos avances en la investigación social (La investigación social de segundo orden)", Antropos, no 22.

ISLA, O. (2003): "El desarrollo tecnológico como detonador de algunas de las crisis epistemológicas que enfrentan las ciencias de la comunicación”, Razón y Palabra, junio-julio de 2003.

Itami, H. y Roehl, Th. W. (1987): Mobilizing Invisible Assets. Cambridge, MA: Harvard University Press.

Kahneman, D., Slovic, P. y Tversky, A. (eds.) (1982): Judgment under uncertainty: Heuristics and biases. New York: Cambridge University Press.

Kahneman, D. y TVersky, A. (1973): “On the psychology of prediction”, Psychological Review, 80, pp. 237-251.

KaPlan, R. y NorTon, D. (1996): The Balanced Scorecard: Translating Strategy Into Action. Boston, MA: Harvard Business School Press.

Kelly, G. (1979): The Psichology of Personal Constructs. New York: Norton. 
Kendall, R. (1997): Public Relations Campaign Strategies. Boston: Allyn \& Baycon.

KNOWER, F. (1966): "The present state of experimental speech-coomunication research”, en RIED, P. (ed.): The frontiers of experimental speech-coomunication. Syracuasa, New York.

Kunsch, M. (2003): Planejamento de ralaçôes públicas na comunicaçâo integrada. Sao Paulo: Summus.

LAkoff, G. (2008): The Political Mind. Penguin Group.

LARA, B. (2009): Blog de www.tendencias2 1.net, 8 de diciembre de 2009.

Laszlo, C. y Laugel, J.-F. (1998): L'economie du chaos. Paris: Editions d'Organisation.

LAWREnCE, P. y LoRsCH, J. (1967): Organization and environment. Boston: Harvard University. Edición española (1987): La empresa y su entorno. Barcelona: Plaza \& Janés.

Lewontin, R. C. (2000): The Triple Helix: Gene, Organism and Environment. Cambridge, MA: Harvard University Press. Edición española: Genes, organismo y ambiente. Barcelona: Gedisa.

Lotman, Y. (1998): La semiosfera. I. Semiótica de la cultura y del texto. Madrid: Cátedra, pp. 21-42.

Macías, N. y CARDONA, D. (2007): Comunicometodología: Intervención social estratégica. Instituto Internacional de Filosofía.

MACLEAN, P. (1990): The triune brain in evolution: role in paleo cerebral functions. New York: Plenum.

ManuCCI, M. (2004): Comunicación corporativa estratégica. De la persuasión a la construcción de realidades compartidas. Bogotá: SAF Grupo.

ManUCCI, M. (2005): Atrapados en el presente. La comunicación, una herramienta para construir el futuro corporativo. Quito: CIESPAL.

MANUCCI, M. (2005b): "Narraciones corporativas. Comunicación, estrategia y futuro en las organizaciones". Disponible en http://www.estrategika.com.ar/articulos.htm 
MANUCCI, M. (2006): La estrategia de los cuatro círculos. Bogotá: Norma.

MAnUCCI, M. (2008): Impacto corporativo. Buenos Aires: La Crujía.

MARChIORI, M. (2006): Cultura e comunicaçâo organizacional. Sâo Caetano do Sul: Difusâo.

MARín, C. (1971): Elaboración del mensaje publicitario. Madrid: Instituto Nacional de Publicidad.

MARQuÉS DE MELO, J. (2002): "Política, dimensión hegemónica en el pensamiento comunicacional latinoamericano", Oficios Terrestres, año VIII, nº 11-12 (Número Especial).

Martín SERRANO, M. (1981): Epistemología de la comunicación y análisis de referencia. Madrid: AC.

Martín Serrano, M. (1982): Teoría de la comunicación. Epistemología y análisis de referencia. Madrid: Universidad Complutense.

Martín-BARBero, J. (2002): Oficio de cartógrafo. Travesías latinoamericanas de la comunicación en la cultura. Bogotá: Fondo de Cultura Económica.

MARTÍN-BARBERO, J. (2003): "Comunicación fin de siglo ¿Para dónde va nuestra investigación?”, Innovarium.

Massoni, S. (1990): La comunicación como herramienta estratégica. Argentina: Secretaría de Estado de Agricultura, Ganadería y Pesca / INTA / Pergamino.

MASSONI, S. (2005): "Estrategias como mapas para navegar un mundo fluido", Fisec-estrategias, año I, no 2. Disponible en http://www.fisec-estrategias.com.ar/

Massoni, S. (2007): Estrategias. Los desafíos de la comunicación en un mundo fluido. Rosario: Homo Sapiens.

Massoni, S. (2007b): Comunicación estratégica. Experiencias, planificación e investigación en marcha. Rosario: Agencia Nacional de Promoción Científica y Tecnológica / Universidad Nacional de Rosario.

MATILla, K. (2008): Los modelos de planificación estratégica en la teoría de las relaciones públicas. Barcelona: UOC. 
MATO, D. (2001): "Estudios y otras prácticas latinoamericanas en cultura y poder: Crítica de la idea de 'Estudios Culturales Latinoamericanos' y propuestas para la visibilización de un campo más amplio, transdisciplinario, crítico y contextualmente referido", ponencia preparada para el Primer Encuentro Internacional sobre "Estudios culturales latinoamericanos: Retos desde y sobre la región andina", Quito, 13-15 de junio.

Maturana, H. y Varela, F. (1984): El árbol del conocimiento, Bases biológicas del entendimiento humano. Organización de Estados Americanos.

May, S. y Mumby, D. K. (eds.) (2005): Engaging Organizational Communication Theory and Research: Multiple Perspectives. Thousand Oaks, CA: Sage.

Maynard SMith, J. (1982): Evolution and the Theory of Games. Cambridge University Press.

MAYR, E. (2005): Así es la biología. Madrid: Debate.

McPheE, R. y ZAUG, P. (2000): “The communicative constitution of organizations: A framework for explanation”, Electronic Journal of Communication.

MinZBergt, H. (1973): The nature of Managerial Work. New York: Harper \& Row.

Minzbergt, H. (1978): "Patterns in Strategy Formation”, Management Science, 24, pp. 934-948.

Minzbergt, H. (1987): "Five Ps for Strategy", California Management Review. Reproducido en Mintzberg, H. y Quinn, J. B. (1992): The Strategy Process. Englewood Cliffs NJ: Prentice-Hall International, pp 12-19.

Minzbergt, H. (1994): The Rise and Fall of Strategic Planning. Hemel Hemstead: Prentice Hall International.

Minzberg, H., Ahlstrand, B., Lampel, J. (1998): Strategy Safari. Prentice Hall. Edición en castellano (1998): Safari a la estrategia. Buenos Aires: Granica.

MintzberG, H. y Quinn, J. B. (1992): The strategy process. Englewood Cliffs: Prentice-Hall.

MinzberG, H. y Waters, J. A. (1985): “Of Strategies, Deliberate and Emergent”, Strategic Mangement Journal. 
Mirowski, Ph. (1989): More Heat than Light: Economics as Social Physics, Physics as Nature's Economics. Cambridge, MA: Cambridge University Press.

Moles, A. (1982): “La ciencia de los mensajes”, Cuadernos de Comunicación, nº 83.

Moriello, S. A. (2005): "Los nuevos caminos del conocimiento. Organismos y entorno interactúan para encontrar el significado a partir de una interacción dialéctica”, Tendencias 21, 13/11/2005. Disponible en www.tendencias21.net

Moriello, S. A. (2005b): "Nuevos enfoques en el estudio de la mente", Tendencias 21,19/6/2005. Disponible en www.tendencias21.net

MORIN, E. (1995): Introducción al pensamiento complejo. Barcelona: Gedisa.

MoRin, E. (1996): “El pensamiento complejo: antídoto para pensamientos únicos". Material tomado de la página web de la Biblioteca de Pensamiento complejo: http://216.22.168.217.docum1.htm, diciembre de 1996.

Morin, E. (2003): La Identidad Humana. El Método V. La humanidad de la humanidad. Barcelona: Círculo de Lectores.

Morin, E. (2003): La mente bien ordenada. Barcelona: Seix Barral.

Morin, E. (2008): Encuentro con FISEC en el Chateau d'Orion dentro del ciclo «Croisements de Cultures».

MORRIS, Ch. (1935): Fundation of the theory of signs. Univesity of Chicago Press.

Moss, D. y Warnaby, G. (1998): “Communications strategy? Strategy communication? Integrating different perspectives”, Journal of Marketing Communications, 4, pp. 131-140.

Mumby, D. (comp.) (1997): Narrativa y control social. Buenos Aires: Amorrortu.

MúneRA URIBE, P. A. (2005): El comunicador corporativo: entre la teoría y la práctica. De la etimología de la comunicación a la organización viable. Medellín: Zuluaga.

Múnera URIBe, P. A. (2010): La articulación teoría-práctica en la comunicación. Barranquilla: Universidad Autónoma del Caribe.

MuÑOZ VÁSQUEZ, K. (2006): "Comunicación estratégica como ventaja competitiva de las organizaciones", Fisec-estrategias, $n^{\circ} 3$. Disponible en http://www.fisecestrategias.com.ar/ 
Muriel, M. L. y Rota, G. (1980): Comunicación institucional. Enfoque social de relaciones humanas. Quito: Editora Andina.

Murphy, P. (1989): "Game Theory a Paradigm for the Public Relations Process", en Botan, C. H. y Hazleton, V. JR.: Public Relations Theory. New Jersey: Lawrence Erlbaum Ass.

Mut Camacho, M. (2006): "El director de comunicación, perfil de una nueva figura”, Fisec-estrategias, año 2, $\mathrm{n}^{\circ} \quad 5$. Disponible en http://www.fisecestrategias.com.ar/

Nalebuff, B. J., y Branderburger, A. M. (1997): "Co-opetition: Competitive and cooperative business strategies for the digital economy”, Strategy \& Leadership, vol. 25 nº 6, pp. 28-35. Edición en español (1996): Coo-petencia. Bogotá: Norma.

Oliveira, I. L. (2002): Dimensâo estratégica da comunicaçâo no contexto organizacional contemporáneo: un paradigma dde ineteraçao dialógica. UFRJ: Escola ded comunicaçâo. Tese de Ductorado.

Oliveira, I. L. y De Paula, M. A. (2008): O que é comunicaçâo nas oraganizaçôes? Sâo Paulo: Paulus.

Oliveira, I. L. y Nogueira SeOAREs, A. T. (eds.) (2008): Interfaces e tendencias da comunicaçâo no contexto das organizaçôes. San Caetano do Sul: Difusão.

Ormerod, P. (1994): The Death of Economics. London: Faber and Faber.

Orozco Gómez, G. (1997): La investigación de la comunicación dentro y fuera de América Latina. La Plata: Ediciones de Periodismo y Comunicación / Universidad Nacional de La Plata.

Pearce, W. y Cronen, V. E. (1978): Communication meaning in action: The Cration of Social Realities. Nueva York: Praeger.

Penman, R. (1980): Communication processes and relationships. London: Academic Press.

Peters, T. (1987): Thriving in Chaos. New York: Alfred Knopf Vintage Book, Random House Inc. 
Peters, T. y Waterman, R. H. (1984): In Search of Excellence. New York: Warner Books. Edición en castellano: En busca de la excelencia. Barcelona: Plaza y Janés.

Pimienta, D. y BARnola, L. (2001): "La experiencia del proyecto Metodología e Impacto Social de las TIC en América Latina y el Caribe (MISTICA) y la constitución de la red de observación OLISTICA”, en Bonilla, M. y Cliche, G. (eds.) (2001): Internet y sociedad en América Latina y el Caribe. Ecuador: Flacso.

PINKER, S. (2009): The Stuff of Thought: Language as a Window into Human Nature. Penguin Press Science.

Porter, M. E. (1980): Competitive Strategy. New York: Free Press. Edición en castellano (1982): Estrategia competitiva. México: CECSA.

PorTer, M. E. (1985): Competitive Advantage. New York: Free Press.

Prahalad, C. K. y Hamel, G. (1990): “The Core Competence of the Corporation”, Harvard Business Review, 68 (3): pp. 79-87.

Prahalad, C. K. y Hamel, G. (1994): "Strategy as a field: Why Search for a New paradigm”, Strategic Management Journal, 15, pp. 5-16. Traducción española: Enciclopedia práctica del Management, $\mathrm{n}^{\circ}$ 2, Expansión/Harvard Deusto.

Prahalad, C. K. y Hamel, G. (1995): Compitiendo por el futuro. Barcelona: Ariel.

Punset, E. (2011): “Mentes maravillosas”, Muy Interesante, $\mathrm{n}^{\circ}$ 363, agosto de 2011.

Putnam, L., Pacanowsky, M. E. (eds.) (1983): Communication and organizations: an interpretative approach. Beverly Hills, CA: Sage.

Reardon, K. (1981): Persuasion. Theory and Context. Londres: Sage.

REARDON-BOyton, K. (1978): "Conversational deviance: a developmental perspective”. University of Massachusetts.

RiverA, J. B. (1987): La investigación en comunicación social en la Argentina. Buenos Aires: Puntosur.

Rivera, J. B. (1997): Comunicación, medios y cultura. Lineas de investigación en la Argentina, 1986-1996. La Plata: Ediciones de Periodismo y Comunicación / Universidad Nacional de La Plata.

Mediaciones Sociales, № 10, I semestre 2012, pp. 121-196. ISSN electrónico: 1989-0494.

DOI: http://dx.doi.org/10.5209/rev_MESO.2012.n10.39684 
Ronda Pupo, G. A. (2002): "De la estrategia a la dirección estratégica”. Disponible en http://www.5campus.com/leccion/ede. Consultado el 19 de agosto de 2006.

Roveda Hoyos, A. (2007): “¿Es posible la formación de un pensamiento estratégico en las Facultades y Escuelas de Comunicación y Periodismo?”, Signo y Pensamiento, volumen XXVI.

Roveda Hoyos, A. (2008): Informe de Evaluación de los Exámenes de Calidad de la Educación Superior en Comunicación e Información. Asociación Colombiana de Facultades y Programas Universitarios en Comunicación e Información (AFACOM) / Editorial Universidad Externado de Colombia.

RovedA Hoyos, A. (2009): "El Santo Grial de la Comunicación. Claves para la búsqueda del pensamiento estratégico en la facultades y escuelas de Comunicación en Iberoamérica”, Signo y Pensamiento. Publicado también en Fisec-estrategias, año III, $n^{\circ}$ 7, 2007, disponible en http://www.fisec-estrategias.com.ar/

Rowan-Robinson, M. (2002): Los nueve números del cosmos. Madrid: Editorial Complutense.

SÁNCHEZ Ruiz, E. E. (1988): "La investigación de la comunicación y el análisis social en Latinoamérica y en México”, en SÁNCHEz RuIZ, E. E. (comp.): La investigación de la comunicación en México. Logros, retos y perspectivas. México: Ediciones de Comunicación / Universidad de Guadalajara.

SÁnchez Ruiz, E. E. (1995): "La investigación de la comunicación en tiempos neoliberales: Nuevos retos y posibilidades", en GALINDO, J. y LunA, C. (coords.) Campo académico de la comunicación: Hacia una reconstrucción reflexiva. Guadalajara: ITESO / Consejo Nacional para la Cultura y las Artes.

Scheinsohn, D. (2009): Comunicación estratégica. Granica: Buenos Aires.

SCHRAMM, W. (1973): "Investigación de la comunicación en los Estados Unidos”, en Schramm, W. (comp.) La ciencia de la comunicación humana. México: Roble.

SCHultz, D. (1981): Essentials of Advertising Strategy. Chicago: Crain Books.

Schultz, D. y Martin, D. G. (1979): Strategic Advertising Campaigns. Chicago: Crain Books. 
Searls, D. y Weinberger, D., Locke, C., Levine, R. (2000): The Clue Train Manifesto: The End of Business as Usual. Nueva York: Perseus Book.

Shanonn, C. y Weaver, W. (1948): The mathematical Theory of Communication. Urbana: University of Illinois Press. Edición en castellano (1974): Teoría matemática de la comunicación. Madrid: Forja.

Shimanoff, S. B. (1980): Communication rules. Beverly Hills, CA: Sage.

STEyn, B. (2003): Contribution of Public Relations to Organizational Strategy Formulation. Mahwah, N.J.: Lawrence Earlbaum Editors.

THAYER, L. (1963): "On theory building in Communication: some conceptual, problems”, Journal of Communication, 13.

Tironi, E. y Cavallo, A. (2004): Comunicación Estratégica. Vivir en un mundo de señales. Taurus.

TORRICO, E. (1999): Comunicación latinoamericana: Caminos y evaluaciones. La Paz: U. Andina Simón Bolívar.

TORRICO, E. (2004): Abordajes y periodos de la teoría de la comunicación. Buenos Aires: Norma.

Treviño, R. y ARAngo, B. (2001): "La trama, articulación estratégica de acciones para enfrentar los retos ingentes del mundo de hoy”, ponencia en el II Encuentro Internacional de Estrategar, julio de 2011 . Inédito.

UIA (Union of International Associations) (1994): Encyclopedia of World Problems and Human Potential (EWPHP). Munich: K.G. Saur.

UIA (UNION OF INTERNATIONAL ASSOCIATIONS) (1995): International Organization Solution Strategies. Munich: K.G. Saur.

VAn Riel, C. B. M. (1997): Comunicaçâo corporativa. Prentice Hall.

VARELA, F. (1988): Cognitive Science. A cartography of Current Ideas. Paris: CREA. Edición en castellano (1996): Conocer. Barcelona: Gedisa.

VÁSQUEZ MUÑOZ, K. (2004): "Comunicación estratégica como ventaja competitiva de las organizaciones”, Fisec-estrategias, año $2, \mathrm{n}^{\circ} 3$. Disponible en http://www.fisec-estrategias.com.ar/ 
VASSAllo DE Lopes, M. I. (2002): "Reflexiones sobre el estatuto disciplinario del campo de la comunicación”, en VASSALlo DE LoPes, M. I. y Fuentes NAVARRO, R. (comps.): Comunicación: campo y objeto de estudio. Perspectivas reflexivas latinoamericanas. Guadalajara: ITESO / UAA / U. de C. / U. de G.

Villegas, D. (2010): Aportes a una nueva teoría de la estrategia reformulada desde la comunicación. Universidad de Lleida, España. Tesis Doctoral.

Von Neuman, J. y Morgenstern, O. (1944): Theory of Games and Economic Behavior. Pricenton.

Watzlawick, P. (1997): Teoría de la comunicación humana. Buenos Aires: Tiempo Contemporáneo.

Wilcox, D. L., Cameron, G. T., Ault, Ph., Agee, W. (1989): Public Strategies and tactics. Madrid: Pearson Education. 


\section{PARA CITAR ESTE TRABAJO EN BIBLIOGRAFÍAS:}

ALBERTO PÉREZ, Rafael (2012): "El estado del arte en la Comunicación Estratégica”, Mediaciones Sociales. Revista de Ciencias Sociales y de la Comunicación, $\mathrm{n}^{\circ}$ 10, pp. 121-196. DOI: http://dx.doi.org/10.5209/rev_MESO.2012.n10.39684

\section{${ }^{(*)}$ El autor}

Rafael Alberto Pérez es Profesor Emérito de la Universidad Complutense de Madrid; Presidente de Honor del Foro Iberoamericano Sobre Estrategias de Comunicación (FISEC); y profesor invitado de unas 100 Universidades de 14 países. En la actualidad trabaja en formación de directivos (talleres y seminarios in house) por encargo y como consultor estratégico por proyectos. Es consejero de The Blueroom Project - TBP Consulting para temas de turismo y ocio. En el mundo académico imparte cursos y seminarios a nivel internacional.

RECIBIDO: 29 de diciembre de 2011.

ACEPTADO: 20 de abril de 2012. 